\title{
Heritage Module within Legal Translation and Interpreting Studies: Didactic Contribution to University Students' Sustainable Education
}

\author{
Anastasia Atabekova
}

check for

updates

Citation: Atabekova, A. Heritage Module within Legal Translation and Interpreting Studies: Didactic

Contribution to University Students' Sustainable Education. Sustainability 2021, 13, 3966. https://doi.org/ $10.3390 /$ su13073966

Academic Editors: Clemens Mader, Mark Winterbottom and Paola di Giuseppantonio di Franco

Received: 2 March 2021

Accepted: 30 March 2021

Published: 2 April 2021

Publisher's Note: MDPI stays neutral with regard to jurisdictional claims in published maps and institutional affiliations.

Copyright: (C) 2021 by the author. Licensee MDPI, Basel, Switzerland. This article is an open access article distributed under the terms and conditions of the Creative Commons Attribution (CC BY) license (https:/ / creativecommons.org/licenses/by/ $4.0 /)$.
Department of Foreign Languages, Law Institute, RUDN University-Peoples' Friendship University of Russia, 117198 Moscow, Russia; aaatabekova@gmail.com

\begin{abstract}
This article explores the hypothesis that the concept of heritage is relevant for a universitybased degree course in legal translators and interpreters' training. The research rests on the legal and academic understanding of cultural heritage. The study explores its specifics regarding the English-taught discipline on Legal Translation and Interpreting Studies within the above-mentioned graduate program. The research integrates qualitative tools and statistical instruments, starts with the theoretical consideration of legislative and academic sources, proceeds to the empirical studies of heritage samples, and considers their relevance for the heritage module design within the specified discipline. The experimental design of such a module and its use for the training of students are also part of the present investigation that further explores students' perceptions of the heritage module under study, with reference to their future career tracks. The study reveals the specifics and components of the heritage framework for the discipline under study and identifies those areas of professional activities for which students consider the heritage module as most useful and relevant. These issues have not been a subject for academic research so far, which contributes to the research relevance and novelty.
\end{abstract}

Keywords: sustainable development; higher education; legal translators and interpreter training legal translation

\section{Introduction}

Contemporary society faces the increasing role of legal translation and interpreting due to skyrocketing globalization and international cooperation in diverse fields that require administrative and legal regulations of the respected activities [1]. This, in turn, enhances the need for the professional training of legal translators that is traditionally organized within academic institutions through specialized master's programs on translation and interpreting [2].

The digital platforms provide a detailed list of such programs across the world. Their curricula focus on the background knowledge regarding translation and interpreting in general, and its specifics within the specialized domains for the training. Traditionally, the programs include some modules on translation studies, theory, history, and methodology of this discipline, along with the subjects that provide applied training $[3,4]$.

However, practicing translators state that they can translate without theory knowledge. Some of them agree that the above-mentioned theoretical courses enhance the systemic approach to the translation process and the perception of professional standards [5].

Meanwhile, both academia and industry confirm the demand in professional translators and interpreters and underline the need for professionalization in training and practice as it is sure to contribute to the quality of translation and interpreting services $[6,7]$.

A consistent discussion is underway on the curricula content, training, and assessment tools, etc. Against this background, there is a debate over the position of the discipline that focuses on the translation studies development. Scholars warn against the situation 
when the discipline turns into a narrative historiography without connection with the contemporary translation industry activities and prospects [8]; however, they underline that the consideration of the historical development of translation studies and practices really matters, as knowledge of the past helps us to identify current challenges and tailor solutions [9]. Moreover, scholars underline that the historical landscape as a part of translation studies courses, helps students to understand the development of the profession as a social and cultural practice within national and international dimensions [10].

The above leads to the hypothesis that the concept of heritage seems to be relevant for legal translators and interpreters' training.

To test this assumption, the present research started with tailoring the existing legal and academic framework to consider heritage for educational practices and recalled the concept of heritage within language studies and industry. These preliminary considerations of the current data have provided grounds for the research design and implementation. These issues are aggregated within the introduction Sections 1.1 and 1.2, respectively, to further specify the present research angle, goal, subject and object, and research questions as well.

\subsection{Heritage for Sustainable Education: Legal and Academic Framework}

World heritage has become the focus of international community conservation and safeguard policies since the second part of the past century. The Convention Concerning the Protection of the World Cultural and Natural Heritage (1972) made the landmark action for its protection in the form of the world countries' collective obligations and efforts across the world [11]. Policy makers elaborate such an approach in the third millennium. Article 7 of the United Nations Educational, Scientific and Cultural Organization (UNESCO) Universal Declaration on Cultural Diversity (2001) underlines the importance of preserving and enhancing "heritage in all its forms ..." as it is "a record of human experience and aspirations ..." "[12].

Next, it seems critical to bear in mind further distinctions of the heritage type that can be found in the UNESCO documents and official publications. The UNESCO projects specify that the term of cultural heritage incorporates a number of major categories, including "movable cultural heritage (paintings, sculptures, coins, manuscripts), immovable cultural heritage (monuments, archaeological sites, and so on), intangible cultural heritage (oral traditions, performing arts, rituals)", etc. [13].

Along its history, UNESCO has paid specific attention to movable cultural property, specified them as a "testimony of human evolution", underlined their "archaeological, historical, artistic, scientific or technical value and interest" and specifically mentioned in one of its Recommendations (1978) manuscripts and incunabula, codices, books, documents or publications of special interest ... ) [14].

The UNESCO Convention for the Safeguarding of the Intangible Cultural Heritage (2003) in Article 2 has specified the domain of intangible cultural heritage. The list includes oral traditions and expressions, including language and social practices [15].

Article 14 of the mentioned Convention urges for the "recognition of, respect for, and enhancement of the intangible cultural heritage in society, in particular through both educational programs for the general public and specific educational and training programs for particular audiences" [15].

The 2030 Agenda for Sustainable Development of the United Nations Organization (UNO) mirrors the above statement and shapes the goal to foster measures and mobilize resources to "safeguard the world's cultural and natural heritage" in its 11.4. item of the document [16]. The Roadmap on Education for Sustainable Development 2030 further underlines the need to address sustainability challenges and sustainable development goals (SDG) essence through education [17].

Academia reflects on the above international policies and white papers. Scholars follow the international community policies and consistently consider ways to implement the UNESCO recommendations and decisions into the educational policies and practices. 
Researchers have strongly argued for heritage education, which plays a crucial role in the construction of identities with historical consciousness [18]. Researchers agree on the interdisciplinary nature of heritage studies in general [19] and draw particular attention to intangible heritage [20-22].

Educators and researchers cooperate to draft special guidelines for educators to organize the learning/teaching process with the intangible heritage for a sustainable future [23] and map the learning/teaching policies and practices on intangible heritage within the education for sustainable development [24,25].

The above legal and academic background reveals the logic of the discussion on the heritage role regarding language, translation and interpreting education and industry as they focus on language use practice, which according to the international legal instruments and academic sources, can be considered as a kind of intangible heritage within particular contexts.

\subsection{Concept of Heritage within Language Studies and Industry}

First, it should be noted that there are different approaches to the definition and scope of the heritage language concept. Scholars underline this sensitive issue. Thus, Polinsky and Hagan (2007) indicate the particular significance of the heritage language concept for "such languages as Chinese, Arabic, and languages of India and the Philippines, whose inhabitants speak multiple languages or dialects and are considered heritage speakers of a single standard language that is considered as such due to geographic, cultural or other reasons (Mandarin Chinese, Classical Arabic, Hindi, or Tagalog, respectively)" [26]. Meanwhile, another approach views indigenous (minority) languages as well as languages that are commonly spoken in many regions of the world where these languages do not have the status of the state language (Spanish in the United States, Arabic in France) [27].

Academia considers the latter phenomenon from various angles. The areas include the didactics of heritage language learning didactics by children of immigrant families [28], formal heritage language acquisition at schools [29], the issues of curriculum design and implementation [30], and the phenomenon of translanguaging in multilingual classrooms [31], which is considered a relevant approach for multilingual classes [32]. Heritage language learning is also a subject for consideration within the national and cultural identity dimensions $[33,34]$. Researchers also explore ideological aspects of heritage language mastery [35,36] and move the discussion towards the social justice perspective [37].

The concept of the heritage language as a native speaker language that has known the status of the official state language in the country is accepted in the current translation and interpreting studies and practice. The issues of translation and interpreting regarding the heritage language follow the above trends. Scholars explore bilingual youngsters' perceptions of their role as family interpreters [38], consider the special pedagogy for such non-professional interpreters [39], and analyze challenges and opportunities for heritage language learners in interpreting courses in different countries [40]. Special emphasis is laid on ethical heritage interpretation in Indigenous contexts where the interpreter often acts as a researcher [41]. Academia also engages in studies of those specifics that heritage language interpreters face in different professional contexts, including work with sign language [42], the activities of guide-interpreters [43] and of health care workers and medical interpreters [44], and the performance of law-enforcement officers serving as interpreters [45].

However, the available academic data reveal that the concept of heritage as declared and developed under international law and education has not become a subject for comprehensive research within the dimension of Legal Translation and Interpreting Studies. Therefore, bearing in mind the contexts that have been mapped above, we consider it relevant to focus on the heritage phenomenon in relation to Legal Translation and Interpreting Studies, and to conduct a diachronic investigation of the heritage formation within centuries-long translation and interpreting practice and research. 
The considerations in Sections 1.1 and 1.2 have contributed to shape the present research goal, specify its subject and object, and identify the research questions.

The study is two-fold and aims to specify the conceptual framework of heritage for Legal Translation and Interpreting Studies, and to conduct empirical studies regarding the design and implementation of the training module on heritage within the respective discipline.

The research subject is the phenomenon of heritage within Legal Translation and Interpreting Studies as an academic education discipline.

The research objects incorporate the constituent components of this concept, and the perception of their relevance by the graduate students of the master's course on legal translation and interpreting at RUDN University, and graduate students of the master's course on Translation and Interpreting in a number of other Russian Universities that run the module on Legal Translation and Interpreting within their degree programs.

The following research questions are subject to the study:

$R Q 1$ : What are the heritage framework and core conceptual components for Legal Translation and Interpreting Studies?

$R Q 2$ : What didactic pathway can be used for the integration of heritage phenomenon into Legal Translation and Interpreting Studies, with account for students' opinions hereof?

The reply to RQ 1 requires theoretical studies of academic data (analytical reports and research findings) that are supposed to provide the conceptual and theoretical background for the integration of heritage phenomenon into Legal Translation and Interpreting Studies.

The reply to RQ 2 assumes the investigation of teaching practice that can integrate the concept of heritage into the process of training legal translators and interpreters.

\section{Materials and Methods}

The study started in 2012 when the master's course on Legal Translation and Interpreting was launched at RUDN University. The materials for the present article were aggregated from the mentioned year up to the latest graduation of the course students in 2020.

The research materials were collected in line with the research goal and questions. The identification of the heritage framework and conceptual components, as well as the identification of the contents for the module under study, required the collection of academic and legislative sources and public comments from the translation and interpreting academia and industry representatives.

The identification of the didactic pathway for the integration of the heritage phenomenon into Legal Translation and Interpreting Studies, with account for students' opinions hereof, justified the need to design the module contents and communicate with university students who enrolled on the master's program on the legal translation and interpreting program/module to obtain their perceptions and vision of the heritage module.

\subsection{Data Collection of Academic Sources}

The legislative sources were taken from the official UNO-affiliated World Heritage Center (https: / / whc.unesco.org/en/documents/, last accessed on 1 February 2021). The academic data collection was created through Google Scholar to collect the research publications, and through the Google search engine to incorporate applied comments from the professional translators' blogs. In total, over 1457 publications were found in the digital databases (excluding the repetition of topics regarding the region, period and type of heritage), and over 276 items (excluding repetitions) on the heritage items with reference to Legal Translation and Interpreting issues. The data formed the background for the theoretical analysis, experimental design of the heritage module for the discipline under study, and factual material for the students' training.

However, we should underline that the mentioned data differ in terms of concrete sources value for either the identification of the core features of the Legal Translation and Interpreting heritage conceptual framework, or the factual material for the design of 
the heritage module within Legal Translation and Interpreting Studies. Moreover, most academic and blog-based publications (over 70\%) with reference to Legal Translation and Interpreting Studies mention the centuries-long Legal Translation and Interpreting (T\&I) practice and its examples, and consistently explore the interdisciplinary nature of these studies without any reference to the heritage concept. Therefore, only those publications that considered some concrete facts regarding the history of the discipline under study were used for further research.

\subsection{Data Collection for Training}

The resources for the module contents were selected from the compendium of items obtained through the analytical search and consideration of sources for the identification of the heritage framework and conceptual components.

\subsection{Training Module Participants}

As it was mentioned earlier, the module under study and the respective teaching practice have been subject for theoretical background and applied contents update and revision from 2012 to 2020. During this period, 56 graduate students of the RUDN University master's program on Legal T\&I, as well as 123 students of other Russian universities (that offered students the heritage module on Legal Translation and Interpreting Studies), were invited to express their opinions on the module in the format of individual interviews on the grounds of the questionnaire list. Age, gender, academic record, career aspirations, employment experience, and social background were considered as potential variables. The respondents asked to keep their personal data regarding their name and surname and the university they graduated from confidential.

\subsection{Methods}

The study rested on the qualitative approach and combined desk and field research. The theoretical investigation aimed to identify the legal and academic background for the heritage framework consideration. The data were organized into the respective corpus of the academic texts that were processed through the Qualitative Data Analysis (QDA) Minor Lite (https: / / qda-miner-lite.software.informer.com/1.2/, last accessed on 1 February 2021).

The empirical studies included the experimental design of the heritage module for the discipline under study, its implementations, and the investigation of students' opinions. The first edition of the module was designed in 2012 and further tested within the mentioned educational settings from 2012 to 2020. The course contents were updated across the mentioned period due to the students' pool preferences.

The legislative, academic, and public comment sources that were found in the course of present research in relation to the history of Legal T\&I studies form the contents of the training toolkit for the heritage module.

The teaching methodology rested on the learner-centered, task-, inquiry- and projectbased approaches.

To explore the students' opinions of the module, a list of open-ended questions was drafted to explore students' perceptions of the materials under consideration, and the questionnaire included the following items:

1. Do you think the heritage module within Legal T\&I Studies can be:

(a) included

from the discipline syllabus?

If the answer is $A$, please proceed to the next question.

If the answer is $B$, please explain reasons for the reply choice.

2. What areas of contribution of the heritage module in the discipline under study can be identified?

(a) Historical framework of the discipline development, 
(b) Academic knowledge of the discipline development,

(c) Awareness of legal translation and interpreting as a social practice phenomenon,

(d) Understanding the historical development of the legal translation and interpreting profession.

Please feel free to specify or modify each variant of the answer with your own comment.

3. How would you characterize the academic relevance of the heritage module in the discipline under study?

(a) It provides deeper and more systemic knowledge of the overall discipline,

(b) It stimulates research skills,

(c) To bridge theory and practice, past and present of the academic studies and professional activities.

Please feel free to specify or modify each variant of the answer with your own comment.

4. How would you characterize the heritage module in the discipline under study with reference to your future career?

(a) The module has limited value,

(b) The module is useful for further research careers,

(c) The module can be useful for the career of the university-based translator's trainer.

Please feel free to specify or modify each variant of the answer with your own comment.

The above questionnaire was first used for oral individual interviews with students and further formed the background frame for students' written replies with extended individual comments. The collection of the respective texts was closed by May 2020 (in line with the graduation of the latest pool of the participants in the training module under consideration).

\subsection{Instrumental Tools}

The QDA Minor Lite was used to process the corpus of academic texts. The system texts from the google data base were uploaded into the QDA Miner. The system text search tools provided the coding of the corpus items on the grounds of keyword search and section retrieval and the identification of the similar text segments through their automatic grouping.

The Statistical Package for the Social Sciences (SPSS) was used to implement cluster, factor, and discriminant types of analysis of respondents' written opinions of the heritage module.

\section{Results and Discussion}

This part integrates data and their interpretation according to the research goal and questions. In line with the latter, this part includes two sections. Each one starts with the description of the obtained findings and proceeds to the discussion that comments on them in view of the quest statements.

\subsection{Heritage Framework and Core Conceptual Components for Legal Translation and Interpreting Studies}

This section introduces theoretical analysis of the academic data and provides discussion and interpretation in line with the first research question. The findings highlight outcomes of theoretical studies to shape the background for the integration of the heritage phenomenon into Legal Translation and Interpreting Studies. 


\subsubsection{Findings}

The study of academic publications and cultural artefacts has made it possible to identify a number of critical provisions that shape the heritage framework for the discipline under study. The analysis revealed the comprehensive nature of the heritage phenomenon for the discipline under study. Therefore, the description of findings is further divided into several subsections.

\section{Translation of Heritage as Part of Social Practice}

The analysis of sources reveals that contemporary Humanities and Social Sciences view translation as a long-standing social practice that contributes to providing solutions for sustainable development through cross disciplinary mechanisms which integrate multilingual communication, healthcare, law, politics, education, environmental policy, geological and cultural heritage conservation, etc. [46].

Both the public and academia recognize translation and interpreting activities as a tool for the representation of national identity within the forward-moving globalization [47,48], on the one hand, and underline the respective practices' role and significance for the protection and raising awareness of cultural heritage [49].

Along with advancing technology and skyrocketing internationalization, scholars specifically focus on the sensitivity of translation with regard to human civilization and cultural heritage while considering translation standards, tactics, and techniques, with the aim of introducing the intangible heritage of Eastern countries, including China [50], India [51], Thailand [52], Egypt [53], Indonesia [54], etc., to the western communities. Researchers also explore translation issues for national intangible heritage dissemination across European cultures [55,56].

Specific attention is paid to the role of translation with regard to religious studies, which are conducted across different religions within a particular period of history, including, for instance, the role of the representation of Judaism, Christianity and Islam in the heritage items of Late Antique and Early Medieval cultures [57] and the ideology in the religious translation of Sikhism in postcolonial India [58].

Translation potential is explored for intangible heritage conservation within the area of appraisal of archival sources for the formation of a documentary heritage for the benefits of society [59].

The preservation of indigenous people's heritage for its cross-cultural transfer through translation as an interdisciplinary tool is a subject for research as well $[60,61]$.

In the course of exploring translation as an interdisciplinary social practice for cultural heritage preservation, scholars pay specific attention to the scope of the mentioned activity which focuses on various cultural language dependent practices of intangible heritage item transfer, and engage in debates on appropriation, substitution, transculturality, translanguaging, etc., Refs. [62-65] as terminological and procedural specifics of the process and outcomes of the cross cultural and cross language transfer of information on particular national heritage items.

The above material confirms that the development of civilizations viewed translation and interpreting as a social practice. Therefore, the material confirmation of the above statement is relevant for the inclusion of the heritage concept into the academic training of interpreters and translators.

Ancient Artefacts on Translators, Interpreters, and Translation Products

The investigation of the research data shows that the Ancient World has kept for us a number of architectural and sculptural artefacts that depict translators and interpreters across cultures. The present section aims to provide a set of examples that enhance contemporary awareness of the translation profession and legal communication emergence in the Antiquity.

The Near East brings the first mention of the profession from Ancient Sumer. According to the research of M Chrobok [66], clay tablets (typical artefacts of this region) 
were found a with a list of words in cuneiform (dated 2600-2450 BCE) that included the expressions "to interpret literally".

Scholars also mention that the relatively high position of the word in the list which specifies various professions in a temple point may refer to the professional rank in the social hierarchy [67] (pp. 13-38). Ancient Egypt brings to the public a legendary basrelief [68] (now in the National Museum of Leiden, the Netherlands) which depicts a person engaged in interpreting. This bas-relief dates back to the III millennium BC and is considered one of the oldest pieces of evidence of interpreters' existence; scholars suggest that the smaller figure of the interpreter refers to his lower status in the Ancient Egyptian community [69].

The tomb of Horemheb, who was a vizier of authority at the court of three Pharaohs, and further a Pharaoh himself (1333-1306 BC), contains his bas-relief, which introduces him as an interpreter [70].

The famous Rosetta Stone [71], discovered in Egypt and now in the British Museum display, has provided the further generation with three versions of King Ptolemy V Epiphanes (Memphis, Egypt, 196 BC) in hieroglyphic (on the top) script, Demotic (in the middle) script, and in Ancient Greek (at the bottom). The artefact can be considered an example of diachronic translation which provided grounds for the transfer of texts from more ancient forms of language to later ones.

Based on a comparative analysis of the texts, the French Egyptologist F. Champollion conducted the comparative analysis of the texts and discovered the key to restore the ancient Egyptian language and basic legal terminology as well [72].

The Stele of Hammurabi preserves the Code of Hammurabi, which is considered one of the earliest written, most complete, and a harsh legislation text. The code was introduced by the Babylonian king Hammurabi, who reigned in central Mesopotamia (present-day Iraq) from c. 1894 to 1595 BC. The Stele was discovered in Persia in 1901 and is now in the Louvre, France [73].

Scholars have found that the titles of the princes in the tombs of the Princes of Elephantine on Qubbet el-Hawa (a hill near Aswan) contain the term which means supervisor of chief of interpreters [74] (p. 16).

The Old Kingdom text contains a specific language unit, which Egyptologists translate as an "interpreter" [75].

Further, scholars indicate [74] (p. 16) that the scripts of the King Neferirkare period mention interpreters as members of the Egyptian expeditions and armies as well as serving at the dynasty courts [74].

Herodotus (Greek historian of the 5th century BC) mentioned dragoman (interpreters) among the casts that existed in Egyptian society [76].

Scholars have found that a functional professional difference was drawn between the interpreter who engaged in supporting the live contacts and translators who served to ensure written diplomatic communication [77]. Moreover, by the XIV-XIII centuries BC, sources recorded information about a specific interpreter/translator of Ancient Egypt who was the high priest Tinis Ankhurmes [76].

In the texts of the Old Kingdom, scholars have found a special language unit, which is interpreted by Egyptologists as "interpreter" [78].

With reference to the first historical evidence of the linguistically verbalized mention of interpreting during the 3rd millennium BC, scholars also mention the Aswan scriptures, which are the oldest surviving literal artefacts. They mention that the Egyptians had interpreters/translators in the person of the princes of Elephantine [79].

Scholars also identify mentions of interpreters in the Punic language that come from Cyprus [66] and bilingual Phoenician-Hittite inscriptions [67] (p. 24).

The above-mentioned artefacts provide an initial round for further consideration of the legal heritage as a subject for translation activities. 
Translation of Legal Heritage: Interdisciplinary Nature

The investigation has revealed three major dimensions that discover the interdisciplinary nature of legal T\&I heritage. These dimensions appear as follows:

- Translation of legal heritage as the process of legislation and legal science development;

- Translation of legal heritage as the development and analysis of translation procedures and practices;

- Legacy of Legal T\&I Studies forms a part of heritage.

The research made it possible to provide a comprehensive profile of the abovementioned dimensions' essence. The explanation follows below.

First, the translation of legal heritage contributed a lot to the process of legislation and legal science development.

Legal translation is a specific subfield of translation studies and practices due to its strong relation to the comprehension of legal concepts, doctrines, systems, and procedures, juridical knowledge thereof, their specific cultural and social phenomena, and their historical development. Scholars emphasize the need to take the respective differences into account in the course of translation [80], underline the role of language in the perception of foreign legal models [81], and specify the reasons for potential failures in legal translation due to the incongruity of legal systems at both national and international levels [82].

Academia underlines that legal translation plays a crucial role in making legal heritage available for further generations and the development of law as both international and national treasure that organizes and regulates the life of society. Legal translation practice has really brilliant examples of those techniques that prove to be relevant for the legal texts' translation quality, readability, and perception of further generation lawyers. Thus, at the beginning of the 20th century, Harper (1904) provided a detailed list of supporting tools for the code of Hammurabi (2250 BC), including a glossary, index of subjects, lists of proper names, signs, numerals, corrections and erasures, etc. [83].

Scholars lay specific emphasis on the fact that the translation of legal heritage makes a strong contribution to the diachronic representation of national legal systems' development within the international development of legal thought, schools, and practices. The relevant examples can be found with regard to Islamic legal debates on the secular cultural heritage of multinational and multicultural states [84], Russian Law development in general [85], France's legal heritage [86], and Roman legal heritage in European culture [87]. The above explains the consistent attempt of legal translation specialists to remind us of the importance of legal translation quality as a tool for better protection of cultural heritage in general, and that of legal heritage in particular [88].

Second, the translation of legal heritage incorporates the focus on translation procedures and practices' development. We should bear in mind that a centuries-long practice of multilingual translation of legal documents that today we view as legal culture artefacts can be explored as a kind of social and professional practice within a particular period of time.

For instance, the translation procedure of international treaties in Ancient Egypt (the most active period covers 1279 to 1213 BC, during the reign of Pharaoh Ramses II, according to Boules [89]) reveals that, for instance, the agreement between the Egyptians and the Hittite king Hattusilis was first drafted in Babylonian, then was translated into Egyptian and edited by Ramses, re-translated into Babylonian, and sent to the Hittite king [90]. Such a sequence of translation procedures represents a kind of holistic approach to translation [91], which requires several editing stages to balance the legal text content in several languages.

The research confirms that the Antiquity practiced multilingual international documents that were drafted according to the above-mentioned procedures [92].

The Old Russian experience also shows similar practices, though with some specifics. The first steps in legal document translation refer to the agreements, which Prince Oleg concluded with Byzantium in 911 and 944 . The translation of the first documents from the Greek language into the Old Slavonic language was made first by Bulgarians who 
mastered both the Greek and Old Slavonic alphabet, and the final version was presented by the Russian scribe. However, under such a such a procedure, the final text included international terms given in Greek, without translation, and this sometimes led to the misunderstanding of legal obligations [93].

A similar situation was found in other countries which were in transition from the use of Greek and Latin to their national vernacular in legal proceedings during the 17-18th centuries. The scripts confirm that in German practice some parts of the court decision, comments and texts were orally produced in spoken German and further literally (wordto-word) translated into Latin; in the course of such an action, German words were often replaced by Latin ones that often did not refer to a particular text context and content [94]. A step forward was made during the rule of Prussian King Frederick II, when the translation of the texts in Latin was accompanied by the explanations in German [95], thus introducing a respective legal translation tool. The creation of the Code of Napoleon in 1804 entailed its translation for all nearby territories. Comparing translations of the code into German, Šarčević (1997) reveals the desire of translators to "get away" from word-to-word and to create a national legal terminology in German [96]. Such a trend confirmed the importance of the balance and congruity within bilingual or multilingual communication in the legal domain, allowing for commentary and explanations as the translation tools.

The above practice origin can be found in the particular multilingual practices within the translation of legal heritage texts.

For instance, during the Medieval period, there was a specific focus on the translation of Aristotle's work from Greek/Arabic into Latin. Therefore, a specific and really largescale project under the title the Basilica represents both the translation and adaptation of Justinian's Institutes, Digest, Codex and the Novellae. The University of Groningen research team under Prof. H.J. Scheltema produced a modern critical edition of the text, with glosses and critical and explanatory comments [97]. Another eye-catching experience refers to the medieval legal text Lo Codi, which was originally produced in the twelfth century in Occitan (a language of Southern France and Catalonia). This text has been translated in French, Castilian, Latin and Franco-Provencal. Researchers confirm that Lo Codi is a kind of adaptation of the Summa Trecensis, and not a mere translation [98]. Therefore, medieval practices in multilingual legal documents' translation put on the agenda the question on the balance between the necessary adaptation and its possible limits.

Third, the legacy of Legal Translation and Interpreting Studies should be considered as a part of heritage.

Academia operates with the words heritage and legacy. We follow those scholars who accept that the concept of heritage refers to the history, traditions, and qualities of the national, social group, etc., that have been passed on for many years, while legacy is the current situation that exists due to some actions in the past [99-101].

There is a long-standing tradition in Humanities to explore the legacy of theoretical and applied research of the previous periods. This fully references Translation Studies in general, and Legal Translation Studies in particular.

For instance, there is such a genre as a historical reader or an anthology of essays of outstanding scholars of the past. As far as translation studies are concerned, the book by Weissbort and Eysteinsson [102] can be set as an example of such a reader, as it includes a collection of primary texts on translation across history, from the Antiquity to the twentieth century, and incorporates excerpts of personal commentaries, letters, interviews, autobiographies and translation samples of famous experts and translators of the past. Furthermore, the genre of anthology is also popular in translation studies as it provides the historical landscape and development of the scientific discipline through the text translations and respective commentaries of distinguished specialists in translation across history, for instance, from Dryden (1613-1700) to Derrida (1930-2004) [103].

There is a flourishing number of research editions on a particular translation school's historical development $[104,105]$, or a concrete personality who made an outstanding con- 
tribution to the progress and advance in research for the scientific and applied development of the discipline [106-108]. What also seems important is the analysis of translation practices of religious texts (such as that of the Bible or the Qur'an, etc.). These kinds of social practices (see, for instance, $[109,110]$ ) reveal the integrated impact of a particular historical period's ideology, religion, and philosophy on the development of national philosophy, culture, identity and vernacular language.

The above refers to legal translation studies as well. There is a considerable number of research works that explore the origins of legal translation in the Antiquity and summarize the aggregated legacy of the centuries-long research in the field under study [111].

\subsubsection{Discussion}

The above sections make it possible to specify the conceptual framework of heritage for Legal Translation Studies.

The concept under study incorporates items of tangible movable cultural heritage (sculptures representing interpreters and translators, manuscripts of translated legal documents, as well as analytical works' commentaries on translation practice) and immovable cultural heritage (monuments and archeological sites which depict translators and represent the products of their work), as well as intangible cultural heritage (time-tested knowledge and skills regarding translation and interpreting as a social practice in legal settings)—see Figure 1.

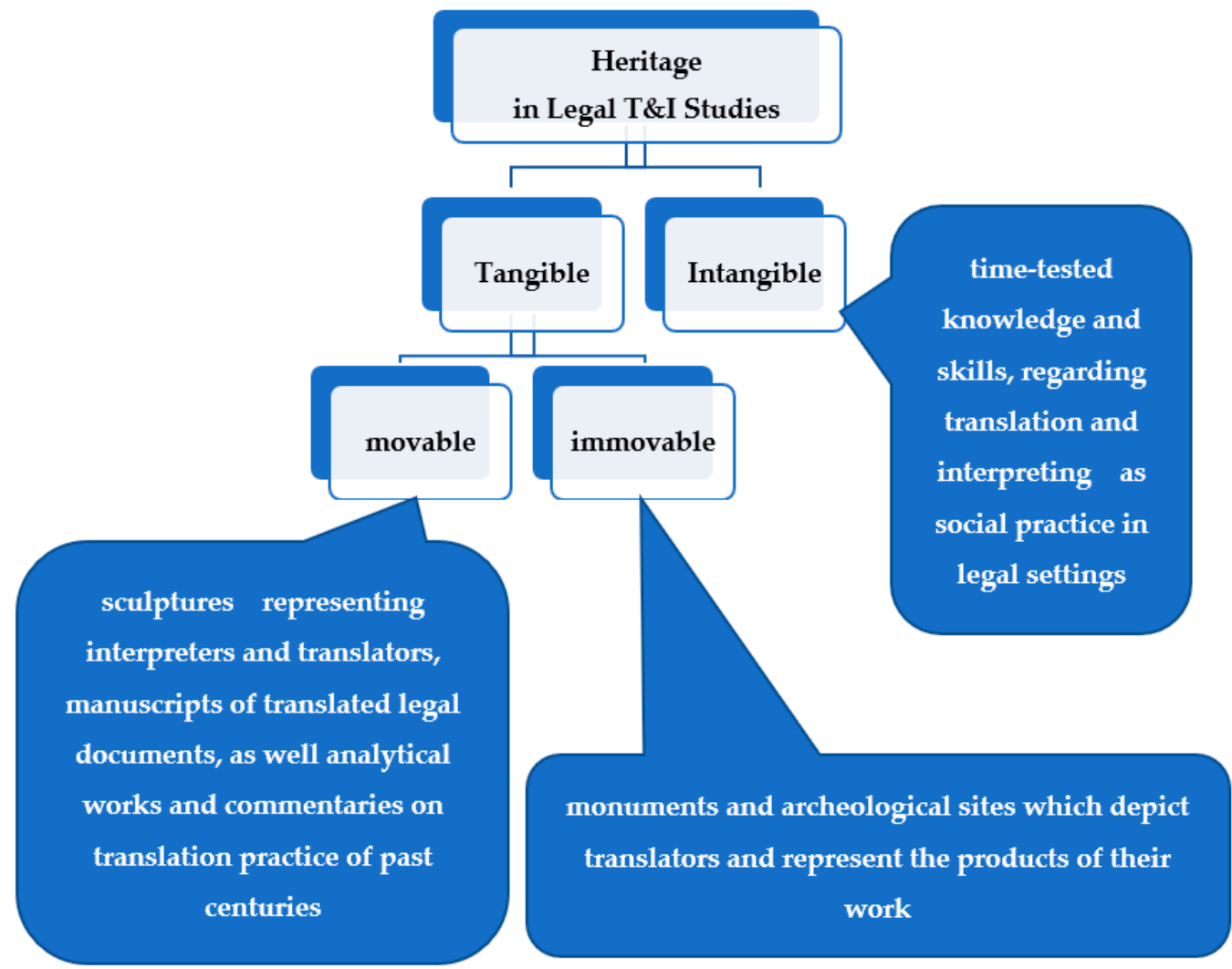

Figure 1. Conceptual Framework for Legal Translation and Interpreting Studies, Author's data.

We suggest to consider the above items as the constituent components of the heritage concept within Legal T\&I studies. The respective items within the above fields are recognized, accepted, and shared within the public, professional, and academic community as the above sample sources confirm through their mention and argumentative use in professional discussions and considerations. Such a state of affairs contributes to fostering the sustainability of the heritage concept's inclusion in the minds, perceptions, and practices of those who are part of the activities related to Legal Translation and Interpreting [112]. 
In general, the above findings acknowledge the deep historical roots of the modern industry of interpreting and translation in general, and those in the legal domain in particular [113]. Moreover, the findings further the idea of legal translation and interpreting multiple perspectives, multidimensional knowledge [114], and skills as a part of heritage from the past and the essence of multimodal cross-civilizational legacy for the modern representatives of academia and the legal translation and interpreting industry.

This research also reveals the core components of the heritage concept for Legal Translation and Interpreting Studies, see Figure 2.

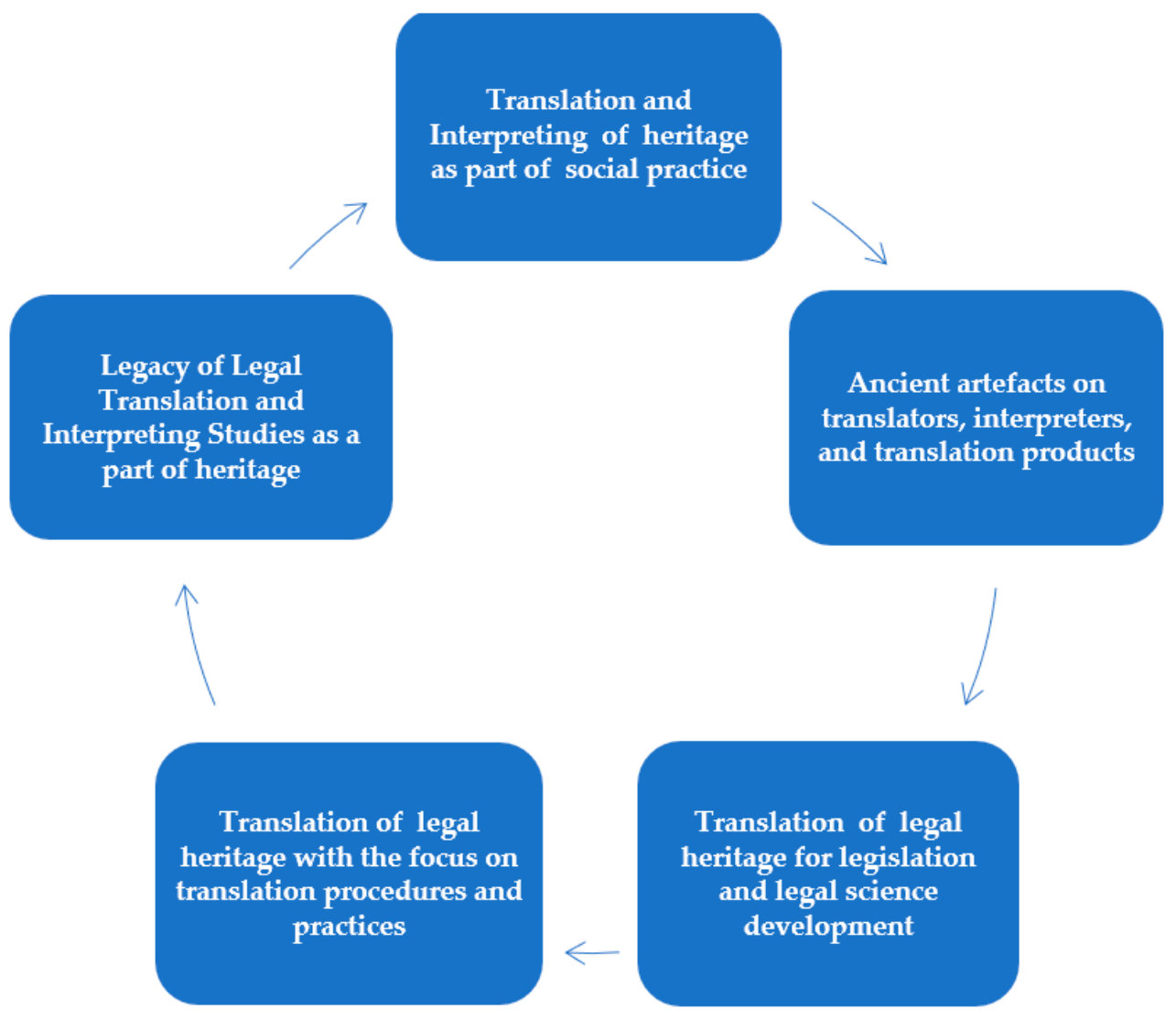

Figure 2. Core components of the heritage concept for Legal Translation and Interpreting Studies, Author's data.

Therefore, the results allow the author to follow the traditional vision of the heritage concept as offered by international law and practice (see the mentioned documents of UNESCO in Section 1.1 of the present paper) on the one hand, and to enhance the concept of heritage within Legal Translation and Interpreting Studies through the implementation of an integrated approach, on the other. It should be mentioned that such a trend correlates with similar directions in the heritage reconceptualization towards the integration of the Ancient and later (even Modern) periods' artefacts and practices-examples can be found with reference to architecture [115,116], agriculture [117], and medicine [118]. Moreover, some scholars underline that narratives of the modern researchers and specialists who engage in the preservation and interpretation of "intangible heritage from within the built heritage paradigm" ... "should be reconceptualized as a storytelling activity. This will offer greater opportunities for intangible heritage to be consolidated within the built heritage paradigm, by encouraging professionals to see themselves as narrators of intangible heritage as well as custodians of physical heritage" [119] (pp. 1-2).

To our mind, the above findings reveal the need to revisit the contents and target indicators of the T\&I Studies discipline. The traditional approach implies the module (lecture/workshop) on the history of Legal T\&I as part of the discipline on general and 
practical issues/theoretical issues in specialized translation. The format of the module is a kind of teacher's narrative on the landmark stages and events across the development of the respective theory and practice and the students' individual reading of the recommended sources for further thematic presentations on the history and personalities who contributed to shaping the profile of the discipline under consideration [120,121]. Such an approach provides background information on the landmark steps within the discipline's development.

However, the narratives and readings as such can hardly contribute to education for sustainable development that is supposed to remove the barrier between the world of work and education, to prepare the skilled and intellectual manpower for the labor market, and to conduct permanent re-skilling and updating the competencies of the specialists-to-be in line with emerging tasks and needs [122].

Therefore, we consider it relevant to bridge the contents of the above-mentioned constituent components of the heritage concept within LT\&I with the current assignments and challenges that professionals might face, as well as those solutions that accumulate the legacy of the past and include pathways which are tailored to modern professional settings. This step will put the module on heritage within the overall ontology [123] of the T\&I Studies discipline as that one which bridges the past and present of the T\&I profession, and provides an integrated response to current demands of both academia and industry. Such an approach goes in line with the general trend to consider heritage education as a tool for sustainable development [124]. The suggested focus is supposed to enhance the awareness of the systemic nature and continuity of the translation education and profession against the background of cross-civilizational time and space dimensions, and to foster the understanding of LT\&I heritage values for contemporary university policies and practices. Academia underlines the importance of these features in education for sustainable development [125].

\subsection{Didactic Pathway for the Integration of Heritage Phenomenon into Legal Translation and Interpreting Studies, with Account for Students' Opinions Hereof}

This section introduces the findings of the empirical studies and provides the discussion and interpretation of the results in line with the second research question. As it was mentioned earlier, the reply to this question requires the investigation of teaching practice that integrated the concept of heritage into the process of training legal translators and interpreters. Such an integration was implemented in the form of a special module on heritage within the course on Legal Translation and Interpreting Studies. We consider it relevant to recall that the material explored in the previous Section 3.1, the investigation of heritage and its conceptual framework with reference to Legal Translation and Interpreting Studies, has provided the background for the module contents and its structure.

\subsubsection{Findings}

Due to the comprehensive nature of $\mathrm{RQ} 2$, this section is further divided into two subsections. The first one describes the tentative design of the heritage module within the discipline under study. The second one focuses on graduate students' opinions regarding the heritage module in Legal Translation and Interpreting Studies.

Module on Heritage in Legal Translation and Interpreting for Sustainable Professional Career

The module is offered under the title of Heritage in Legal Translation and Interpreting for a sustainable professional career. The suggested wording seems critical as it delivers a clear message regarding the purpose of the module as one aimed at theoretical knowledge and applied skills enhancement within the development of the legal translator and interpreter's profession. The module workload combines four contact hours (two and two) and $8 \mathrm{~h}$ for self-studies, with the discipline on Legal Translation and Interpreting Studies' total workload of two credits (72 h) and 36 contact hours. 
The module is subject to study during a two-week period. The module includes eight subthemes. Its architecture follows the flipped classroom didactics and rests on the learning multimodal resources that are available in the university learning management system (LMS) for each student of the course. Students are kindly asked to engage in self-studies of materials before the classroom activities. The sources for training include the author's collection of open access internet sources to watch and read, and academic publications to read and search for materials for brief presentations in the class. The list of the module subthemes, assignments and activities, as well as time management and slots for class activities, is provided in Table 1. The list of tentative sources for self-studies and group discussions for each subtheme is introduced in Appendix A (Table A1) to avoid the disruption of the main text flow. However, the materials are to be updated each year due to new data and students' individual preferences.

Table 1. Contents of Heritage Module within Legal T\&I Studies, Author's data.

\begin{tabular}{|c|c|c|}
\hline $\begin{array}{l}\text { N of Subtheme } \\
\text { in the Module }\end{array}$ & $\begin{array}{l}\text { Title of Subtheme } \\
\text { Examples of and Comments on Assignment Types } \\
\text { (Tentative Sources are Provided in Appendix A) }\end{array}$ & $\begin{array}{l}\text { Time Management and } \\
\text { Slots for Class Activities }\end{array}$ \\
\hline Subtheme 1 & Heritage: Legal and Academic Framework & The 1st Contact Hour \\
\hline $\begin{array}{l}\text { Self-studies in the flipped } \\
\text { classroom mode }\end{array}$ & $\begin{array}{c}\text {-First insights—reading and listening in English (UNESCO } \\
\text { materials) }\end{array}$ & \\
\hline $\begin{array}{l}\text { Assignment for } \\
\text { individual/classroom } \\
\text { activities }\end{array}$ & $\begin{array}{c}\text {-Test (designed by the teacher) on the types of heritage } \\
\text {-Test (design by students to share and exchange in the group) to } \\
\text { identify the types of heritage } \\
\text {-The tests are performed within the Moodle LMS and scores are } \\
\text { counted automatically }\end{array}$ & $\begin{array}{l}30 \text { min classroom } \\
\text { summary by teacher and } \\
\text { students on the tests } \\
\text { results }\end{array}$ \\
\hline Subtheme 2 & Concept of Heritage within Language Studies and Industry & \\
\hline $\begin{array}{l}\text { Self-studies in the flipped } \\
\text { classroom mode }\end{array}$ & -Reading: UNO and UNESCO documents & \\
\hline $\begin{array}{l}\text { Assignment for } \\
\text { individual/classroom } \\
\text { activities }\end{array}$ & $\begin{array}{l}\text {-Individual essays on different approaches to understand language } \\
\text { as heritage or a tool for heritage interpretation and respective } \\
\text { implications for professional career dimensions and requirements; } \\
\text { to be written and uploaded into the university LMS for the } \\
\text { teacher's comments and evaluation }\end{array}$ & $\begin{array}{l}30 \text { min classroom } \\
\text { discussion of the essays }\end{array}$ \\
\hline Subtheme 3 & $\begin{array}{c}\text { Translation and Interpreting of Heritage as Part of Social } \\
\text { Practice }\end{array}$ & The 2 nd contact hour \\
\hline $\begin{array}{l}\text { Self-studies in the flipped } \\
\text { classroom mode }\end{array}$ & $\begin{array}{c}\text {-Video on the concept of heritage interpretation } \\
\text {-Reading: translation and interpreting as tools for awareness raising } \\
\text { of world cultural heritage }\end{array}$ & \\
\hline $\begin{array}{l}\text { Assignment for } \\
\text { individual/classroom } \\
\text { activities }\end{array}$ & $\begin{array}{c}\text {-To find and characterize a sample heritage interpreting/translation } \\
\text { as social practice for world culture preservation } \\
\text {-A group is divided into } 3 \text { sub teams } \\
\text {-Students' briefs in the classroom }\end{array}$ & 30 min for 3 groups' briefs \\
\hline Subtheme 4 & $\begin{array}{c}\text { Ancient Artefacts on Translators, Interpreters, and Translation } \\
\text { Products }\end{array}$ & \\
\hline $\begin{array}{l}\text { Self-studies in the flipped } \\
\text { classroom mode }\end{array}$ & $\begin{array}{l}\text {-Visual sources in the web from the museums and Wikipedia } \\
\text { sources (Egyptian bas-reliefs, Rosetta Stone, Manuscripts, St. } \\
\text { Jerome picture, etc., example: } \\
\text { https: / www.youtube.com/ watch?v=wmqf8XNB9us, last accessed } \\
\text { on 1 February 2021) }\end{array}$ & \\
\hline $\begin{array}{l}\text { Assignment for } \\
\text { individual/classroom } \\
\text { activities }\end{array}$ & $\begin{array}{c}\text {-To select an ancient artefact and to explain why it can matter for } \\
\text { the present-day T\&I activities } \\
\text {-Students' briefs in the classroom }\end{array}$ & 30 min for 3 groups' briefs \\
\hline
\end{tabular}


Table 1. Cont.

\begin{tabular}{|c|c|c|}
\hline $\begin{array}{l}\text { N of Subtheme } \\
\text { in the Module }\end{array}$ & $\begin{array}{l}\text { Title of Subtheme } \\
\text { Examples of and Comments on Assignment Types } \\
\text { (Tentative Sources are Provided in Appendix A) }\end{array}$ & $\begin{array}{l}\text { Time Management and } \\
\text { Slots for Class Activities }\end{array}$ \\
\hline Subtheme 5 & $\begin{array}{c}\text { Translation of Legal Heritage for Legislation and Legal Science } \\
\text { Development }\end{array}$ & The 3rd contact hour \\
\hline $\begin{array}{l}\text { Self-studies in the flipped } \\
\text { classroom mode }\end{array}$ & Readings on the legal heritage translation & \\
\hline $\begin{array}{l}\text { Assignment for } \\
\text { individual/classroom } \\
\text { activities }\end{array}$ & $\begin{array}{c}\text {-To select a sample of legal document translation of the past and to } \\
\text { explain the benefits of legal heritage translation for legal science } \\
\text { and legislation development within national and international } \\
\text { dimensions } \\
\text {-Students' briefs in the classroom }\end{array}$ & 30 min for 3 groups' briefs \\
\hline Subtheme 6 & $\begin{array}{l}\text { Translation of Legal Heritage: Focus on Translation Procedures } \\
\text { and Practices }\end{array}$ & \\
\hline $\begin{array}{l}\text { Self-studies in the flipped } \\
\text { classroom mode }\end{array}$ & $\begin{array}{l}\text { Readings and analysis of selected legal heritage } \\
\text { translation/interpreting }\end{array}$ & \\
\hline $\begin{array}{l}\text { Assignment for } \\
\text { individual/classroom } \\
\text { activities }\end{array}$ & $\begin{array}{c}\text {-To select a sample of legal document translation of the past and to } \\
\text { explain the relevance of its translation procedure analysis for the } \\
\text { present (with reference to particular legal settings) } \\
\text {-Students' briefs in the classroom }\end{array}$ & 30 min for 3 groups' briefs \\
\hline Subtheme 7 & Legal Translation Studies Legacy as a part of Heritage & The 4th contact hour \\
\hline $\begin{array}{l}\text { Self-studies in the flipped } \\
\text { classroom mode }\end{array}$ & Readings and summary of the prominent works of the past & \\
\hline $\begin{array}{l}\text { Assignment for } \\
\text { individual/classroom } \\
\text { activities }\end{array}$ & $\begin{array}{c}\text {-To select a research/commentary of a prominent personality of the } \\
\text { past and explain the relevance of his/her work for the present } \\
\text { research or applied work } \\
\text {-Students' briefs in the classroom }\end{array}$ & 30 min for 3 groups' briefs \\
\hline Subtheme 8 & $\begin{array}{l}\text { The revision of the materials under study, the analysis of the } \\
\text { ISO standards on Legal Translation and Legal Interpreting }\end{array}$ & \\
\hline $\begin{array}{l}\text { Self-studies in the flipped } \\
\text { classroom mode }\end{array}$ & $\begin{array}{c}\text { The revision of the materials under study, the analysis of the } \\
\text { International Organization for Standardization (ISO) standards on } \\
\text { Legal Interpreting [126] and Legal Translation [127] }\end{array}$ & \\
\hline Classroom activities & $\begin{array}{l}\text { Quiz: Students are suggested to draw the matching lines between } \\
\text { the major findings of the T\&I Studies Heritage Module and the } \\
\text { provisions of the International Standards on legal translation and } \\
\text { interpreting. }\end{array}$ & $\begin{array}{l}15 \text { min for the quiz } \\
\text { (performed individually in } \\
\text { writing) and } 15 \text { min for its } \\
\text { check and discussion }\end{array}$ \\
\hline
\end{tabular}

It should be noted the module aims to enhance students' skills in academic discussion on the topics under study, and to bridge the experience of the past and the present requirements of academia and industry in the field of legal T\&I. This purpose is reached through the combination of self-studies, tests, and classroom activities in the form of mini teams' brief presentations of their assignment. After all the groups' briefs, the teacher encourages a summary from the members of the group on the examples and messages that were delivered.

The module requires very strict time management due to the large amount of material to be processed and the limited period of time for class activities under the module.

The evaluation procedure takes into account self-studies (30\% of scores), participation in the classroom activities, including brief presentations and summaries thereof $(50 \%)$, and quiz performance ( 20 items for matching).

The resources for self-studies and classroom activities of the outlined subthemes are introduced in Table A1 of Appendix A in order not to overload the article text with tables. 
Graduate Students' Opinions Regarding the Heritage Module in Legal Translation and Interpreting Studies

The research moved forward with mapping the respondents' opinions regarding the module under study. The written versions of students' replies to the questionnaire items in the course of the individual interviews were processed into word files and were subject to automated analysis that revealed a number of thematic clusters that structured the respondents' views. It should be mentioned that the students replied in more detailed and varied ways in comparison with the list of answer options that was initially offered to them.

The data processing revealed the following clusters:

- Areas of contribution of the heritage module in the discipline under study, see Table 2;

- Academic benefits of the heritage module in the discipline under study, see Table 3;

- Career benefits of the heritage module in the discipline under study, see Table 4 .

Table 2. Clusters characterizing the respondents' views on the areas of contribution of the heritage module in the discipline under study, Author's data.

\begin{tabular}{lc}
\hline \multicolumn{1}{c}{ Clusters } & $\begin{array}{c}\text { Percentage of Respondents } \\
\text { Who Mentioned the Point }\end{array}$ \\
\hline Historical framework of the discipline development & $100 \%$ \\
\hline International dimensions of the discipline development & $98 \%$ \\
\hline Academic knowledge of the discipline development & $98 \%$ \\
\hline $\begin{array}{l}\text { Understanding of legal translation and interpreting as an } \\
\text { international social phenomenon }\end{array}$ & $96 \%$ \\
\hline Understanding of legal translation as a kind of social practice & $94 \%$ \\
\hline $\begin{array}{l}\text { Awareness of legal translation and interpreting as a profession } \\
\text { that was shaped through long-standing social practice }\end{array}$ & $94 \%$ \\
\hline $\begin{array}{l}\text { Understanding of the historically shaped specific } \\
\text { interdisciplinary knowledge and skills }\end{array}$ & $94 \%$ \\
\hline $\begin{array}{l}\text { Understanding of professional challenges and standards as their } \\
\text { continuity and variety within cross civilizational dimensions }\end{array}$ & $89 \%$ \\
\hline $\begin{array}{l}\text { The awareness of challenges to legal translation as a social } \\
\text { practice }\end{array}$ & $76 \%$ \\
\hline
\end{tabular}

Table 3. Clusters characterizing respondents' views on the academic benefits of the heritage module in the discipline under study, Author's data.

\begin{tabular}{lc}
\hline \multicolumn{1}{c}{ Clusters } & $\begin{array}{c}\text { Percentage of Respondents } \\
\text { Who Mentioned the Point }\end{array}$ \\
\hline Deeper and more systemic knowledge of the overall discipline & $96 \%$ \\
\hline Improvement of the professional academic background & $94 \%$ \\
\hline $\begin{array}{l}\text { Additional knowledge for theoretical research in terms of sources } \\
\text { and examples }\end{array}$ & $89 \%$ \\
\hline $\begin{array}{l}\text { Greater experience in engagement in academic discussion on } \\
\text { professional themes Additional research skills to bridge theory } \\
\text { and practice, past and present of the academic studies and } \\
\text { professional activities }\end{array}$ & $88 \%$ \\
\hline
\end{tabular}


Table 4. Clusters characterizing respondents' views on the career benefits of the heritage module in the discipline understudy, Author's data.

\begin{tabular}{lc}
\hline \multicolumn{1}{c}{ Clusters } & $\begin{array}{c}\text { Percentage of Respondents } \\
\text { Who Mentioned the Point }\end{array}$ \\
\hline $\begin{array}{l}\text { Contribution to the comprehensive professional background in } \\
\text { the field of translation and interpreting research (at Master and } \\
\text { PhD degree thesis) }\end{array}$ & $100 \%$ \\
\hline $\begin{array}{l}\text { Contribution to the career opportunities in teaching at university } \\
\text { level }\end{array}$ & $94 \%$ \\
\hline $\begin{array}{l}\text { Contribution to the intellectual level as part of the professional } \\
\text { development for managerial positions in academia and industry }\end{array}$ & $89 \%$ \\
\hline
\end{tabular}

Further, we provide the structured profile of the statements that shaped each cluster, and indicate the cluster density through the percentage of respondents who mentioned the points within the respective cluster.

The discriminant analysis identified as statistically significant the respondents' employment experience $\left(\lambda=0.243, \chi^{2}=4.65, p<0.01\right)$ and students' career aspirations $\left(\lambda=0.341, \chi^{2}=3.65, p<0.02\right)$.

The analysis confirmed the relevance of the heritage module suggested concept for those students who either just thought of a further academic career within higher education or had already combined MA studies with first steps into university-based translation and interpreting teaching. Those students who were planning administrative careers at university language departments also acknowledged the current importance of the offered module for the comprehensive curriculum that could reveal the development of the academic discipline and profession of the translator and interpreter in society. Graduates who planned to enter the language service industry were less active in the module evaluation and mentioned that the data of the heritage module were interesting in terms of history and culture as such. However, this sort of audience also expressed the idea of heritage data use for the purpose of advertising legal T\&I services as the practice whose importance and quality have been shaped across history.

\subsubsection{Discussion}

The above findings provide the reply to the second research question, namely characterizing the didactic pathway for the integration of the heritage phenomenon into Legal Translation and Interpreting Studies, and identify students' opinions on the didactic materials and tools under study.

The results go in line with the modern pedagogical implications on interactivity as an important part of academic studies [128]. The module under study operates with the theoretical data. However, the consistent use of the interactive class work format, in line with the flipped classroom methodology that encouraged individual studies, turned historical narratives into creative discussions and a broader vision of particular historical data with reference to modern trends in academia and industry [129]. Such an opportunity with regard to the theoretical nature of the heritage module follows the tradition of interactive heritage education.

Meanwhile, the use of digital sources of information can be further enhanced and upgraded to the digital story telling practice [130] in the heritage module on legal translation and interpreting. The experimental training revealed that students are interested in this kind of tool incorporation into their briefs. However, due to the large amount of factual materials, there were limited timing capacities for such work.

It seems really important that the interviews revealed a number of perceptions of clusters with regard to different dimensions, i.e., areas of the module contributions and academic and career benefits of the heritage module in the discipline under study. This sends a clear message on the module under study's relevance for university-based sustainable 
training of legal translators and interpreters in line with the multidimensional professional market demands [131].

The design of the experimental course and the procedure of its contents and instruments' testing integrated a number of didactic techniques, including student-centered, task-, inquiry-, and project-based learning. The students' satisfaction upon the course's completion reveals that the theoretical disciplines, which are traditionally seen as the area of a standard combination of lectures and seminars, today require revisiting in terms of their formats, which students prefer to be more flexible, holistic, and interactive.

Finally, we consider it important to underline that the configuration of the module's subthemes shows students the origins of Legal Translation and Interpreting Studies, indicates pathways of the discipline's contemporary developments, and reveals the commitment of contemporary researchers $[95,132]$ to the centuries-long paradigm of the respective knowledge and practice in the field across humankind's history.

\section{Conclusions}

The findings and their discussion aimed to provide a consistent reply to the research questions. The data obtained and processed, as well as their interpretation within the qualitative analytical paradigm, enhance the understanding of the heritage concept with reference to the academic discipline of Legal Translation and Interpreting Studies.

The materials under consideration and the angle of their study prove that the heritage phenomenon regarding a particular domain of translation and interpreting, i.e., law and legislation, obtains specific components and features in comparison with the traditional concepts that operate within the world cultural heritage dimensions. It seems logical due to a concrete field specificity.

Thus, the findings have provided a clear and structured profile of heritage components when considering the legal translation and interpreting phenomenon. The analysis has allowed the specification of kinds of tangible heritage, including movable heritage (sculptures of legal interpreters, manuscripts of translated legal documents, as well analytical works and commentaries on translation practices of past centuries) and immovable heritage (monuments and archaeological sites which depict translators and represent the products of their work). Further clarification of the essence of intangible heritage, which covers time-tested knowledge and skills regarding translation and interpreting as a social practice in legal settings, lays grounds for a comprehensive understanding of the historical development of legal translation challenges and quality, whose standards are embedded in modern international standards (ISO).

Further, the suggested identification of the core components of the heritage concept for Legal Translation and Interpreting Studies has made it possible to reconsider this concept as a multifaceted phenomenon that incorporates translation as an array of artifacts and translation as a social practice for multidimensional purposes, including national legal systems' development, multilingual studies, translation techniques' investigation, and the development of product quality requirements and standards.

The theoretical, analytical and empirical data confirmed the hypothesis that the concept of heritage seems to be relevant for legal translators and interpreters' training.

The research results can be included in the university curriculum regarding diverse career tracks. Thus, a further theoretical research path will allow graduates to focus on the archives' data and search for nation specific artefacts regarding legal T\&I practice and its significance for the state legal system and culture formation and development. The graduates' engagement in university-based translator and interpreter training will require attention to the identification of past and present challenges and practices and legal T\&I, as well as the comparative study of prominent scholars' work across history, to provide a comprehensive profile of the academic discipline's development. The data on the cross-civilizational development of legal T\&I contribute to the industry's social and professional image as that of a long-standing cross civilizational practice of humankind. 
This study reveals those critical instruments, the use of which can provide for the above-mentioned comprehensive vision of the legal translator and interpreter profession's development. Such lenses meet the angle of integrated understanding of the contemporary language service industry.

The suggested approach to the analysis of the heritage framework and conceptual components' importance in legal translation and interpreting provides an example of a holistic approach to the methodology regarding the investigation of the topic under study.

The present research has not avoided some limitations. They might refer to the selection of heritage examples that mostly focus on a particular region. However, it should be noted that the heritage module, when taught for students who learn different foreign languages, incorporates examples that are related to different language and culture communities. Further, the module introduced as an example refers to the English-medium instruction environment. The national universities of different countries can take the architecture of the module to design it in a particular language. The pool of participants can be further enhanced to wider audiences, including students, teachers, and practitioners, and include representatives of other countries as well. Moreover, the perspective of the gender-focused discussion on culture needs to be included in further studies on students' sustainable education on legal translation and interpreting.

Funding: The publication has been prepared with the support of the RUDN University Program Priority2030.

Institutional Review Board Statement: Not applicable.

Informed Consent Statement: Not applicable.

Data Availability Statement: Data is contained within the article.

Conflicts of Interest: The author declares no conflict of interest.

Appendix A. The Training Toolkit for the Heritage Module, Author's Data

(Institutional access to the online library resources is provided to students). 
Table A1. The list of tentative sources for self-studies and group discussions for each subtheme of the heritage module.

\begin{tabular}{|c|c|c|}
\hline Source Types/Titles & Sub-Themes and Source Items & Links to Websites \\
\hline \multicolumn{3}{|c|}{ Sub-theme 1. Heritage: Legal and Academic Framework } \\
\hline Video source: & UNESCO materials: & $\begin{array}{l}\text { https://whc.unesco.org/data } \\
\text { last accessed on } 1 \text { February } 2021\end{array}$ \\
\hline \multirow[t]{4}{*}{ Legislation } & $\begin{array}{c}\text { Convention Concerning the Protection of the World Cultural and Natural } \\
\text { Heritage. UNESCO: Paris, France, 1972. Available online }\end{array}$ & $\begin{array}{l}\text { https:/ / whc.unesco.org/archive/convention-en.pdf. } \\
\text { last accessed on } 1 \text { February } 2021\end{array}$ \\
\hline & Universal Declaration on Cultural Diversity; UNESCO: Paris, France, 2001 & 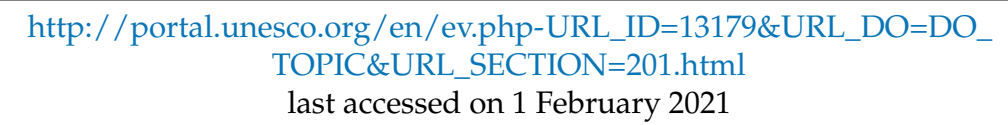 \\
\hline & What is meant by "cultural heritage"? UNESCO & $\begin{array}{c}\text { http://www.unesco.org/new/en/culture/themes/illicit-trafficking-of- } \\
\text { cultural-property/unesco-database-of-national-cultural-heritage-laws / } \\
\text { frequently-asked-questions/definition-of-the-cultural-heritage/ } \\
\text { \#topPage } \\
\text { last accessed on 1 February } 2021\end{array}$ \\
\hline & $\begin{array}{c}\text { Recommendation for the Protection of Movable Cultural Property; UNESCO: Paris, } \\
\text { France, } 1978\end{array}$ & 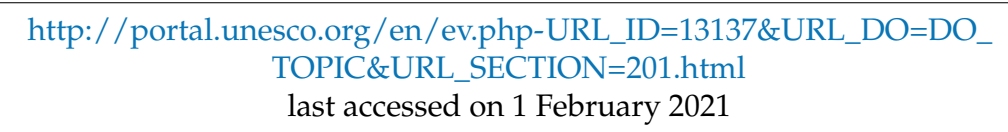 \\
\hline \multirow[t]{4}{*}{ Academic research } & $\begin{array}{l}\text { Ahmad, Y. The scope and definitions of heritage: from tangible to intangible. Int. } \\
\text { J. Herit. Stud. 2006, 12, 292-300. }\end{array}$ & $\begin{array}{l}\text { https:/ / doi.org/10.1080/13527250600604639 } \\
\text { last accessed on } 1 \text { February } 2021\end{array}$ \\
\hline & $\begin{array}{l}\text { Nas, P.J.M. Masterpieces of Oral and Intangible Culture: Reflections on the } \\
\text { UNESCO World Heritage List. Curr. Anthropol. 2002, 43, 139-148. }\end{array}$ & $\begin{array}{l}\text { https: / doi.org/10.1086/338287 } \\
\text { last accessed on } 1 \text { February } 2021\end{array}$ \\
\hline & $\begin{array}{l}\text { Schmit, T.M. The UNESCO Concept of Safeguarding Intangible Cultural Heritage: } \\
\text { Its Background and Marrakchi Roots. Int. J. Herit. Stud. 2008, 14, 95-111. }\end{array}$ & $\begin{array}{l}\text { https: / / doi.org/10.1080/13527250701844019 } \\
\text { last accessed on } 1 \text { February } 2021\end{array}$ \\
\hline & $\begin{array}{l}\text { Akagawa, N., Smith, L., Eds. Safeguarding Intangible Heritage: Practices and Politics; } \\
\text { Routledge: London, UK, } 2018 .\end{array}$ & $\begin{array}{l}\text { https:/ / www.routledge.com/Safeguarding-Intangible-Heritage- } \\
\text { Practices-and-Politics / Akagawa-Smith/p/book/9781138580749 } \\
\text { last accessed on } 1 \text { February } 2021\end{array}$ \\
\hline
\end{tabular}


Table A1. Cont.

\begin{tabular}{|c|c|c|}
\hline Source Types/Titles & Sub-Themes and Source Items & Links to Websites \\
\hline \multicolumn{3}{|c|}{ Sub-theme 2. Concept of Heritage within Language Studies and Industry } \\
\hline \multirow[t]{4}{*}{ Video sources } & UNESCO & $\begin{array}{c}\text { https: / /ich.unesco.org/en/ } \\
\text { https:/ / www.youtube.com/watch?v=aDLi8rAhWks } \\
\text { last accessed on } 1 \text { February } 2021\end{array}$ \\
\hline & Heritage Language, lecture by Harvard Prof. Maria Polinsky & $\begin{array}{l}\text { http:/ / serious-science.org/heritage-language-416 } \\
\text { last accessed on } 1 \text { February } 2021\end{array}$ \\
\hline & $\begin{array}{c}\text { What is heritage language? Lecture from The Audiopedia } \\
\text { https:/ / www.youtube.com/watch?v=aDLi8rAhWks } \\
\text { Heritage language learners }\end{array}$ & $\begin{array}{c}\text { https:/ / www.youtube.com/watch?v=aDLi8rAhWks } \\
\text { Heritage language learners, } \\
\text { https: / / relearnalanguage.com/heritage-languages-9-most-asked-qa/ } \\
\text { last accessed on 1 February } 2021\end{array}$ \\
\hline & Heritage language learners & $\begin{array}{c}\text { https:/ / relearnalanguage.com/heritage-languages-9-most-asked-qa } \\
\text { last accessed on } 1 \text { February } 2021\end{array}$ \\
\hline \multirow[t]{3}{*}{ Academic research } & $\begin{array}{l}\text { Brinton, D.M., Kagan, O., Bauckus, S., (Eds.). Heritage Language Education: A New } \\
\text { Field Emerging; Routledge: London, UK, } 2017 .\end{array}$ & $\begin{array}{c}\text { https:/ / www.routledge.com/Heritage-Language-Education-A-New- } \\
\text { Field-Emerging/Brinton-Kagan-Bauckus/p/book/9780415995887 } \\
\text { last accessed on 1 February } 2021\end{array}$ \\
\hline & $\begin{array}{l}\text { Montrul, S. Heritage language development: Connecting the dots. Int. J. Biling. } \\
\qquad 2018,22,530-546 .\end{array}$ & $\begin{array}{l}\text { https:/ / doi.org/10.1177/1367006916654368 } \\
\text { last accessed on } 1 \text { February } 2021\end{array}$ \\
\hline & $\begin{array}{c}\text { Little, S. Whose heritage? What inheritance? Conceptualising family language } \\
\text { identities. International J. Biling. Educ. Biling. 2020, 23, 198-212. }\end{array}$ & $\begin{array}{c}\text { https: / / doi.org/10.1080/13670050.2017.1348463 } \\
\text { last accessed on } 1 \text { February } 2021\end{array}$ \\
\hline \multicolumn{3}{|c|}{ Sub-theme3. Translation and Interpreting of Heritage as Part of Social Practice } \\
\hline \multirow[t]{2}{*}{ Videos } & $\begin{array}{l}\text { Neil Silberman on Heritage Interpretation \& Presentation at the Your Place or } \\
\text { Mine Conference }\end{array}$ & $\begin{array}{l}\text { https: / / www.youtube.com/watch?v=8GqUUpb3zeM } \\
\text { last accessed on } 1 \text { February } 2021\end{array}$ \\
\hline & What is heritage interpretation & $\begin{array}{c}\text { https:/ / www.youtube.com/watch?v=ITaz2uJSW5g } \\
\text { last accessed on } 1 \text { February } 2021\end{array}$ \\
\hline Academic research & $\begin{array}{l}\text { Saipradist, A.; Staiff, R. Crossing the cultural divide: Western visitors and } \\
\text { interpretation at Ayutthaya World Heritage Site, Thailand. J. Herit. Tour. 2008, 2, } \\
\text { 211-224. }\end{array}$ & $\begin{array}{l}\text { https:/ / doi.org/10.2167/jht061.0 } \\
\text { last accessed on } 1 \text { February } 2021\end{array}$ \\
\hline
\end{tabular}


Table A1. Cont.

\begin{tabular}{|c|c|c|}
\hline Source Types/Titles & Sub-Themes and Source Items & Links to Websites \\
\hline & $\begin{array}{l}\text { Rubenson, S. Translating the Tradition: Some remarks on the Arabization of the } \\
\text { Patristic Heritage in Egypt. Mediev. Encount. 1996, 2, 4-14. }\end{array}$ & $\begin{array}{l}\text { https:// doi.org/10.1163/157006796X00027 } \\
\quad \text { last accessed on } 1 \text { February } 2021\end{array}$ \\
\hline & $\begin{array}{l}\text { Selamet, J. Indonesian Batik Translation: A Case Study. Int. J. Vis. Des. 2018, 12, } \\
\text { 11-17. }\end{array}$ & $\begin{array}{c}\text { https:/ / www.researchgate.net/profile/Juhri-Selamet/publication/3272 } \\
\text { 76995_Indonesian_Batik_Translation_A_Case_Study/links /5f085154458 } \\
\text { 51550509a32b8/Indonesian-Batik-Translation-A-Case-Study.pdf } \\
\text { last accessed on 1 February } 2021\end{array}$ \\
\hline & $\begin{array}{l}\text { Oegema, G.S. The Heritage of Jewish Apocalypticism in Late Antique and Early } \\
\text { Medieval Judaism, Christianity, and Islam. In Vehicles of Transmission, Translation, } \\
\text { and Transformation in Medieval Textual Culture; Wisnovsky, R., Fraenkel, C., Wallis, } \\
\text { F., Claire Fumo, J., Eds.; Brepols Publishers: Turnhout, Belgium, 2012; pp.103-128. }\end{array}$ & $\begin{array}{l}\text { https:/ / doi.org/10.1484/M.CURSOR-EB.1.100260 } \\
\text { last accessed on 1 February } 2021\end{array}$ \\
\hline & $\begin{array}{l}\text { Matusiak, K.K.; Meng, L.; Barczyk, E.; Shih, C.-J. Multilingual metadata for } \\
\text { cultural heritage materials: The case of the Tse-Tsung Chow Collection of Chinese } \\
\text { Scrolls and Fan Paintings. Electron. Libr. 2015, 33, 136-151. }\end{array}$ & $\begin{array}{l}\text { https:/ / doi.org/10.1108/EL-08-2013-0141 } \\
\text { last accessed on } 1 \text { February } 2021\end{array}$ \\
\hline & $\begin{array}{l}\text { EvePocock, C.; Lilley, I. Who benefits? World heritage and Indigenous people. } \\
\text { Herit. Soc. 2017, 10, 171-190. }\end{array}$ & $\begin{array}{l}\text { https:/ / doi.org/10.1080/2159032X.2018.1503836 } \\
\text { last accessed on } 1 \text { February } 2021\end{array}$ \\
\hline & $\begin{array}{l}\text { Nakhodkina, A.A. Cultural heritage in a current context: case of Olonkho } \\
\text { translation. Арктика XXI век. Гуманитарные науки 2015, 2, 86-92. }\end{array}$ & $\begin{array}{c}\text { https: / cyberleninka.ru/article/n/cultural-heritage-in-a-current- } \\
\text { context-case-of-olonkho-translation } \\
\text { last accessed on } 1 \text { February } 2021\end{array}$ \\
\hline \multicolumn{3}{|c|}{ Sub-theme 4. Ancient Artefacts on Translators, Interpreters, and Translation Products } \\
\hline $\begin{array}{l}\text { Tombs of Egyptian princes in the } \\
\text { tombs with the terms that mean } \\
\text { interpreter and supervisor of } \\
\text { interpreters }\end{array}$ & $\begin{array}{l}\text { Kurz, I. The Rock Tombs of the Princes of Elephantine. Earliest References to } \\
\text { Interpretation in Pharaonic Egypt. Babel 1985, 3, 213-218. }\end{array}$ & $\begin{array}{l}\text { https:// doi.org/10.1075/babel.31.4.05kur } \\
\text { last accessed on } 1 \text { February } 2021\end{array}$ \\
\hline $\begin{array}{l}\text { Bas-reliefs which depict } \\
\quad \text { interpreters }\end{array}$ & The Earliest Depiction of an Interpreter $(\mathrm{n} / \mathrm{d})$ & $\begin{array}{c}\text { https:// unprofessionaltranslation.blogspot.com/2010/07/earliest- } \\
\text { depiction-of-interpreter.html } \\
\text { last accessed on } 1 \text { February } 2021\end{array}$ \\
\hline
\end{tabular}


Table A1. Cont.

\section{Source Types/Titles}

The tomb of Horemheb

Wilkinson, T. Writings from ancient Egypt; Penguin: London, UK, 2016.

Rainey, A.F. The El-Amarna Correspondence A New Edition of the Cuneiform Letters

from the Site of El-Amarna based on Collations of all Extant Tablets; 2 Volume set; Brill: Leiden, The Netherlands, 2014.

Tel-el-Amarna Archives

Ray, J. The Rosetta Stone and the rebirth of ancient Egypt; Harvard University Press:

Cambridge, MA, USA, 2007

Rosetta stone

The Code of Hammurabi

The Old Kingdom text contains a specific language unit, which Egyptologists

translate as an "interpreter".

The Old Kingdom text

The scripts of King Neferirkare period

Hermann, A. Interpreting in Antiquity.

Benderitter, T. Qubbat el Hawa. The Tombs of the Asswan Monarchs, 2007.

The Aswan scriptures

Mairs, R. Hermēneis in the Documentary Record from Hellenistic and Roman

Egypt: interpreters, translators and mediators in a bilingual society. J. Anc. Hist. 2020, 8, 50-102.

Sources of XIV-XIII centuries BC

with the information about a

specific interpreter/translator of

\section{Links to Websites}

https:

/ / www.penguin.co.uk/articles/2016/writings-ancient-egypt.html last accessed on 1 February 2021

https: / / brill.com/view/title/15564 last accessed on 1 February 2021

Rosetta Stone (n/d). https:/ / blog.britishmuseum.org/everything-youever-wanted-to-know-about-the-rosetta-stone / last accessed on 1 February 2021

https:/ / www.louvre.fr/en/oeuvre-notices/law-code-hammurabi-kingbabylon

last accessed on 1 February 2021

Baines, J. (2007). Visual and written culture in ancient Egypt. Oxford University Press. last accessed on 1 February 2021

In: The Interpreting Studies Reader, Eds. Pochhacker, F., Shlesinger, M., Eds.; Routledge Language Readers: London, UK, 2002; pp.15-22. last accessed on 1 February 2021

www.osi-risnet.net/tombes/assouan/khoui_herkouf/e_khoui_herkouf. htm.

last accessed on 1 February 2021 Ancient Egypt https:/ / doi.org/10.1515/jah-2019-0001

last accessed on 1 February 2021 
Table A1. Cont.

\begin{tabular}{|c|c|c|}
\hline Source Types/Titles & Sub-Themes and Source Items & Links to Websites \\
\hline \multicolumn{3}{|c|}{ Sub-Theme 5. Translation of Legal Heritage for Legislation and Legal Science Development } \\
\hline $\begin{array}{l}\text { The agreement concluded by the } \\
\text { Egyptians with the Hittite king } \\
\text { Hattusilis (the reign of Pharaoh } \\
\text { Ramses II around } 1280 \mathrm{BC} \text { ), } \\
\text { originally written in Babylonian, } \\
\text { translated into Egyptian, } \\
\text { re-translated into Babylonian. }\end{array}$ & $\begin{array}{l}\text { Langdon, S.M.A.; Gardiner, A.H.; Litt, D. The Treaty of Alliance between } \\
\text { Hattušili, King of the Hittites, and the Pharaoh Ramesses II of EGYPT. J. Egypt. } \\
\text { Archaeol. 1920, 6, 179-205. }\end{array}$ & $\begin{array}{l}\text { https: / / doi.org/10.1177 / } 030751332000600119 \\
\text { last accessed on } 1 \text { February } 2021\end{array}$ \\
\hline $\begin{array}{c}\text { The translation of the Code of } \\
\text { Hammurabi }\end{array}$ & $\begin{array}{l}\text { Harper, R.F. (Ed.) The Code of Hammurabi, King of Babylon, About } 2250 \text { BC: } \\
\text { Autographed Text, Transliteration, Translation, Glossary, in-Dex of Subjects, Lists of } \\
\text { Proper Names, Signs, Numerals, Cor-Rections and Erasures, With Map, Frontispiece } \\
\text { and Photograph of Text; University of Chicago Press: Callaghan, IL, USA, 1904. }\end{array}$ & $\begin{array}{l}\text { https:/ / ia800302.us.archive.org/6/items/cu31924074445523/cu3192407 } \\
\text { 4445523.pdf } \\
\text { last accessed on 1 February } 2021\end{array}$ \\
\hline $\begin{array}{l}\text { Translation of Islamic Legal } \\
\text { Communication and the Russian } \\
\text { Language }\end{array}$ & $\begin{array}{l}\text { Bustanov, A.K; Kemper, M. (Eds). From Mirasism to Euro-Islam: The Translation of } \\
\text { Islamic Legal Debates Into Tatar Secular Cultural Heritage, in Is-Lamic Authority and } \\
\text { the Russian Language: Studies on Texts From European Russia, the North Caucasus and } \\
\text { West Siberia; Pegasus: Amsterdam, Netherlands, } 2012 .\end{array}$ & $\begin{array}{l}\text { https://www.academia.edu/2104539/Islamic_Authority_and_the_ } \\
\text { Russian_Language_Studies_on_Texts_from_European_Russia_the__ } \\
\text { North_Caucasus_and_West_Siberia } \\
\text { last accessed on } 1 \text { February } 2021\end{array}$ \\
\hline $\begin{array}{l}\text { Translating France's Legal } \\
\text { Heritage }\end{array}$ & $\begin{array}{l}\text { Kasirer, N. Translating Part of France's Legal Heritage: Aubry and Rau on the } \\
\text { Patrimoine. Revue Générale Droit 2008, 38, 453-493. }\end{array}$ & $\begin{array}{l}\text { https: / / doi.org / 10.7202/1027043ar } \\
\text { last accessed on } 1 \text { February } 2021\end{array}$ \\
\hline $\begin{array}{l}\text { The Treaty of Waitangi (New } \\
\text { Zealand's founding document) }\end{array}$ & $\begin{array}{l}\text { Crocket, A. Exploring the meaning of the Treaty of Waitangi for counselling. N. } \\
\text { Zealand J. Couns. 2013, 33, 54-67. }\end{array}$ & $\begin{array}{c}\text { https:/ / www.nzac.org.nz/assets/Uploads/Journals/4.-Exploring-the- } \\
\text { Meaning-of-the-Treaty-of-Waitangi-for-Counselling.pdf } \\
\text { last accessed on } 1 \text { February } 2021\end{array}$ \\
\hline
\end{tabular}


Table A1. Cont.

\begin{tabular}{|c|c|c|}
\hline Source Types/Titles & Sub-Themes and Source Items & Links to Websites \\
\hline $\begin{array}{l}\text { 1889, Treaty of Wuchale between } \\
\text { Italy and Ethiopia }\end{array}$ & $\begin{array}{l}\text { Masiola R., Tomei R. Manipulating Treaties. In Law, Language and Translation. } \\
\text { Springer Briefs in Law; Springer: Cham, Switzerland, 2015; pp. 73-94. }\end{array}$ & $\begin{array}{l}\text { https: / / doi.org/10.1007/978-3-319-14271-5_6 } \\
\text { last accessed on } 1 \text { February } 2021\end{array}$ \\
\hline The Meaning of Mokusatsu & $\begin{array}{l}\text { Kawai, K. Mokusatsu, Japan's response to the Potsdam declaration. Pac. Hist. Rev. } \\
\qquad 1950,19,409-414 .\end{array}$ & $\begin{array}{l}\text { https:/ / doi.org/10.2307/3635822 } \\
\text { last accessed on } 1 \text { February } 2021\end{array}$ \\
\hline $\begin{array}{l}\text { Khrushchev's } 1956 \text { Speech at the } \\
\text { Polish Embassy }\end{array}$ & $\begin{array}{c}\text { Birkby, S.J. How mistranslation heightened Cold War Tensions. Galaxy 2013, } \\
\text { online. }\end{array}$ & $\begin{array}{c}\text { http:/ / www.aulibrary.au.edu/multim1/ABAC_Pub/Galaxy-The- } \\
\text { English-Department-Journal/n2-6-2013.pdf } \\
\text { last accessed on } 1 \text { February 2021 }\end{array}$ \\
\hline \multicolumn{3}{|c|}{ Sub-theme 6. Translation of Legal Heritage: Focus on Translation Procedures and Practices } \\
\hline $\begin{array}{l}\text { Multilingual and bilingual } \\
\text { treaties before } 338 \mathrm{BC}\end{array}$ & Scala R. Die Staatsvertrage des Altertums; Leinen: Leipzig, Germany, 1898; pp. 6-12. & $\begin{array}{l}\text { https:/ / doi.org/10.11588/diglit.21699\#0084 } \\
\text { last accessed on } 1 \text { February } 2021\end{array}$ \\
\hline $\begin{array}{l}\text { Laws of } 12 \text { tables, developed by } \\
\text { the Commission } 12 \text { (decemvir) in } \\
\text { the middle of V century BC. e. } \\
\text { ( } 451-450 \text { years) }\end{array}$ & $\begin{array}{c}\text { Steinberg, M. The Twelve Tables and Their Origins: An Eighteenth-Century } \\
\text { Debate. J. Hist. Ideas 1982, 43, 379-396. }\end{array}$ & $\begin{array}{l}\text { https://doi.org/10.2307/2709429 } \\
\text { last accessed on } 1 \text { February } 2021\end{array}$ \\
\hline $\begin{array}{l}\text { The Justinian Code or Corpus } \\
\text { Juris Civilis (Corpus of Civil } \\
\text { Law), a major reform of } \\
\text { Byzantine law created by } \\
\text { Emperor Justinian I (r. 527-565 } \\
\text { CE) in 528-9 CE. }\end{array}$ & $\begin{array}{l}\text { Frederick W. Dingledy, F.W. The Corpus Juris Civilis: A Guide to Its History and Use, } \\
\text { Library Staff Publications 123; William \& Mary Law School Scholarship Repository: } \\
\text { Williamsburg, VA, USA, } 2016 .\end{array}$ & $\begin{array}{l}\text { https://scholarship.law.wm.edu/libpubs/123 } \\
\text { last accessed on } 1 \text { February } 2021\end{array}$ \\
\hline $\begin{array}{l}\text { Translation of Old Russian } \\
\text { Treaties }\end{array}$ & $\begin{array}{c}\text { Macalister-Smith, P.; Schwietzke, J. Treaty Collections Relating to Russia: A } \\
\text { Baseline Historical Survey in Comparative Perspective. Jus Gentium. J. Int. Legal } \\
\text { Hist. 2018, 3, 307. }\end{array}$ & $\begin{array}{c}\text { https: / } / \text { heinonline.org } / \text { HOL } / \text { LandingPage?handle=hein.journals } / \\
\text { jusge3\&div=16\&id=\&page= } \\
\text { last accessed on } 1 \text { February } 2021\end{array}$ \\
\hline $\begin{array}{l}\text { Translation of Laws of Manu } \\
\text { (Ancient India) }\end{array}$ & $\begin{array}{l}\text { Benoit, M. The Intellectual Adventures of William Jones (II): The Justinian of } \\
\text { India. Rev. Société Etudes Anglo-Américaines XVIIe XVIIIe Siècles 2010, 67, 187-202. }\end{array}$ & $\begin{array}{c}\text { https://www.persee.fr/doc/xvii_0291-3798_2010_num_67_1_2510 } \\
\text { last accessed on 1 February 2021 }\end{array}$ \\
\hline
\end{tabular}


Table A1. Cont.

German Experience in legal

translation during past centuries

(translation of laws of Germanic

tribes from the Germanic

vernacular into Latin by clerics; the court proceedings practice of

the translation of the Roman

Heck, P. Ubersetzungsprobleme in fruhen Mittelalter; Tubingen: Mohr, Germany, 1931. From Sarcevic, S. New Approach to Legal Translation, Kluwer Law International B.V, 1997. https: / /books.google.ru/books?id=i8nZijo 9ikC\&pg=PA23\&dq=legal+ translation+history + in +germany\&lr $=\& h l=r u \& s o u r c e=g b s \_t o c \_r \& c a d=$ $3 \# \mathrm{v}=$ onepage $\& \mathrm{q}=$ legal $\% 20$ translation $\% 20$ history $\% 20$ in $\% 20$ germany $\& \mathrm{f}=$ false

last accessed on 1 February 2021

Prussian King Frederick). The translation of the Napoleon Code into German

The translation of the Austrian

Civil Code of 1811 (Allgemeines

Bürgerliches Gesetzbuch) into

Czech, Croatian, Hungarian,

Lorenz, W. General Principles of Law: Their Elaboration in the Court of Justice of the European Communities. Am. J. Comp. L. 1964, 13

https:/ /heinonline.org/HOL/LandingPage?handle=hein.journals/ amcomp13\&div $=6 \&$ id $=\&$ page $=$ last accessed on 1 February 2021

Romanian, Serbian, and Slovenian

The combination of Latin,

English, and Anglo-Norman

French in England in 14th

Ormrod, W.M. The Use of English: Language, Law, and Political Culture in Fourteenth-Century England. Speculum 2003, 78, 750 http:/ / www.jstor.org/stable/20060788 last accessed on 1 February 2021 century

The development of Japanese $\quad$ McArthur, M. Japanese Laws in Translation, Blog, International Association of Laws in translation Law Libraries, 29 July 2014

http://iall.org/japanese-laws-in-translation/ last accessed on 1 February 2021

\section{Sub-theme 7. Legal Translation Studies Legacy as a part of Heritage}

Šarčević, S. New Approach to Legal Translation; Kluwer Law International: The Hague, The Netherlands, 2000 https:/ /books.google.ru/books?id=i8nZijo_9ikC\&pg=PA23\&dq=legal+ translation+history+in+germany\&lr=\&hl=ru\&source $=$ gbs_toc_r\&cad $=$ $3 \# \mathrm{v}=$ onepage \&q=legal $\% 20$ translation $\% 20$ history $\% 20$ in $\% 20$ germany \&f= false 
Table A1. Cont.

Source Types/Titles

Sub-Themes and Source Items

\section{Links to Websites}

Prieto Ramos, F. Legal translation studies as interdiscipline: Scope and evolution. Meta Transl. J. 2014, 59, $260-277$.

https:/ / www.erudit.org/en/journals/meta/1900-v1-n1-meta01604/1 27475ar/abstract/

last accessed on 1 February 2021

http:/ / cejsh.icm.edu.pl/cejsh/element/bwmeta1.element.desklight-62 cc0566-d33b-4f1b-a758-7d8478b40f5e last accessed on 1 February 2021

Schneiderová, A. Historical Background to English Legal Language. J. Mod. Sci. 2018, 37, 117-126.

http:/ / cejsh.icm.edu.pl/cejsh/element/bwmeta1.element.desklight-55 ba0e2d-0295-4600-aac6-737825ba40a8 last accessed on 1 February 2021

https: / / doi.org/10.2307/j.ctt1ckpfkh

last accessed on 1 February 2021 


\section{References}

1. Prieto Ramos, F. (Ed.) Institutional Translation for International Governance. Enhancing Quality in Multilingual Legal Communication; Bloomsbury: London, UK; New York, NY, USA, 2018.

2. Abdel Latif, M.M.M. Translator and Interpreter Education Research. New Frontiers in Translation Studies; Springer: Singapore, 2020.

3. Master Studies. Available online: https://www.masterstudies.com/Masters-Degree/Translation/\#programs (accessed on 1 February 2021).

4. FindMasters. Available online: https://www.findamasters.com/masters-degrees / ?Keywords=legal+translation (accessed on 1 February 2021).

5. Ahmadi Darani, P. Can translators ignore theory in Translation Studies? Researchgate. 18 December 2014. Available online: https:/ / www.researchgate.net/post/Can_translators_ignore_theory_in_Translation_Studies (accessed on 1 February 2021).

6. Orlando, M.; Gerber, L. The impact of globalization on translator and interpreter education. Routledge Handb. Transl. Glob. 2020. [CrossRef]

7. Svoronou, E. Revisiting the Greek and English Legal Term Pairs in the Domains of EU, Civil, Commercial, and Penal Law Based on the Underlying Concepts: A Critical Reflection on Equivalence and the Role of Terminologists and Translators. 2020. Available online: https://termcoord.eu/wp-content/uploads/2020/11/Dissertation_Eleni-Svoronou.pdf (accessed on 1 February 2021).

8. Rundle, C. Translation as an Approach to History. Transl. Stud. 2012, 5, 232-240. [CrossRef]

9. Ahn, I.K. History and challenges of translation and interpreting in Modern Korea: On the 40th anniversary of The Graduate School of Interpretation \& Translation (GSIT) of Hankuk University of Foreign Studies (HUFS). Babel 2020, 66, 550-569. [CrossRef]

10. Sayaheen, B.; Al-Ramadan, R. Implications of Self-and Other-Representation in Representing Translation History: With Special Reference to the History of Translation in the Abbasid Era. J. Educ. Soc. Res. 2020, 10, 157. [CrossRef]

11. Convention Concerning the Protection of the World Cultural and Natural Heritage; UNESCO: Paris, France, 1972; Available online: https: / / whc.unesco.org/archive/convention-en.pdf (accessed on 20 February 2021).

12. UNESCO. Universal Declaration on Cultural Diversity; UNESCO: Paris, France, 2001; Available online: http:/ / portal.unesco.org/ en/ev.php-URL_ID=13179\&URL_DO=DO_TOPIC\&URL_SECTION=201.html (accessed on 20 February 2021).

13. What is Meant by "Cultural Heritage"? UNESCO. Available online: http://www.unesco.org/new/en/culture/themes/illicittrafficking-of-cultural-property / unesco-database-of-national-cultural-heritage-laws/frequently-asked-questions / definitionof-the-cultural-heritage/\#topPage (accessed on 20 February 2021).

14. UNESCO. Recommendation for the Protection of Movable Cultural Property; UNESCO: Paris, France, 1978; Available online: http: / / portal.unesco.org/en/ev.php-URL_ID=13137\&URL_DO=DO_TOPIC\&URL_SECTION=201.html (accessed on 20 February 2021).

15. UNESCO. Convention for the Safeguarding of the Intangible Cultural Heritage; UNESCO: Paris, France, 2003; Available online: http: / / portal.unesco.org/en/ev.php-URL_ID=17716\&URL_DO=DO_TOPIC\&URL_SECTION=201.html (accessed on 20 February 2021).

16. Resolution Adopted by the General Assembly 70/1. Transforming Our World: The 2030 Agenda for Sustainable Development. A/RES/70/1 (25 September 2015). Available online: https:/ / undocs.org/en/A/RES/70/1 (accessed on 20 February 2021).

17. ESD for 2030. Education for Sustainable Development for 2030 Toolbox; ESD: Paris, France; Available online: https://unesdoc.unesco. org/ark:/48223/pf00003748021 (accessed on 20 February 2021).

18. Delgado-Algarra, E.J.; Cuenca-López, J.M. (Eds.) Challenges for the Construction of Identities with Historical Consciousness: Heritage Education and Citizenship Education. In Handbook of Research on Citizenship and Heritage Education; IGI Global: Hershey, PA, USA, 2020; pp. 1-25.

19. Uzzell, D. Where is the discipline in heritage studies? A view from environmental psychology. In Heritage Studies: Methods and Approaches; Sorensen, M.L.S., Carman, J., Eds.; Routledge: London, UK, 2009; pp. 326-333.

20. Ahmad, Y. The scope and definitions of heritage: From tangible to intangible. Int. J. Herit. Stud. 2006, 12, 292-300. [CrossRef]

21. Nas, P.J.M. Masterpieces of Oral and Intangible Culture: Reflections on the UNESCO World Heritage List. Curr. Anthropol. 2002, 43, 139-148. [CrossRef]

22. Schmit, T.M. The UNESCO Concept of Safeguarding Intangible Cultural Heritage: Its Background and Marrakchi Roots. Int. J. Herit. Stud. 2008, 14, 95-111. [CrossRef]

23. Pillai, J. Learning with Intangible Heritage for a Sustainable Future: Guidelines for Educators in the Asia-Pacific Region; UNESCO Office. Regional Bureau for Education in Asia and the Pacific: Bangkok, Thailand, 2015.

24. Akagawa, N.; Smith, L. (Eds.) Safeguarding Intangible Heritage: Practices and Politics; Routledge: London, UK, 2018.

25. Aziz, N.A.A.; Ariffin, N.F.M.; Ismail, N.A.; Alias, A. The Significance of Living Heritage Conservation Education for the Community toward Sustainable Development. Environ. Behav. Proc. J. 2020, 5, 125-131. [CrossRef]

26. Polinsky, M.; Kagan, O. Heritage languages: In the 'wild' and in the classroom. Lang. Linguist. Compass 2007, 1, 368-395. [CrossRef]

27. Valdés, G. Bilingualism, heritage language learners, and SLA research: Opportunities lost or seized? Mod. Lang. J. 2005, 89, 410-426. [CrossRef]

28. Brinton, D.M.; Kagan, O.; Bauckus, S. (Eds.) Heritage Language Education: A New Field Emerging; Routledge: London, UK, 2017.

29. Lohndal, T.; Rothman, J.; Kupisch, T.; Westergaard, M. Heritage language acquisition: What it reveals and why it is important for formal linguistic theories. Lang. Linguist. Compass 2019, 13, e12357. [CrossRef] 
30. Beaudrie, S.; Amezcua, A.; Loza, S. Critical language awareness in the heritage language classroom: Design, implementation, and evaluation of a curricular intervention. Int. Multiling. Res. J. 2021, 15, 61-81. [CrossRef]

31. Rowe, L.W. Say it in your language: Supporting translanguaging in multilingual classes. Read. Teach. 2018, 72, 31-38. [CrossRef]

32. Mulvey, N. Translanguaging, a different pedagogy for language education at a Japanese as a Heritage Language (JHL) School in England. In Doing Education Differently, Proceedings of the 2017 STORIES Conference; Software Integrated Systems: Nashville, TN, USA, 2017; pp. 85-92.

33. Montrul, S. Heritage language development: Connecting the dots. Int. J. Biling. 2018, 22, 530-546. [CrossRef]

34. Little, S. Whose heritage? What inheritance?: Conceptualising family language identities. Int. J. Biling. Educ. Biling. 2020, 23, 198-212. [CrossRef]

35. Canagarajah, S. Changing orientations to heritage language: The practice-based ideology of Sri Lankan Tamil diaspora families. Int. J. Sociol. Lang. 2019, 255, 9-44. [CrossRef]

36. Tseng, A. 'Qué barbaridad, son latinos y deberían saber español primero': Language Ideology, Agency, and Heritage Language Insecurity across Immigrant Generations. Appl. Linguist. 2021, 42, 113-135. [CrossRef]

37. Ortega, L. The study of heritage language development from a bilingualism and social justice perspective. Lang. Learn. 2020, 70, 15-53. [CrossRef]

38. Angelelli, C.V. Bilingual youngsters' perceptions of their role as family interpreters. Non-professional interpreting and translation: State of the art and future of an emerging field of research, In Non-professional Interpreting and Translation: State of the Art and Future of an Emerging Field of Research; Antonini, R., Cirillo, L., Rossato, L., Torresi, I., Eds.; John Benjamins Publishing Company: Amsterdam, The Netherlands, 2017; pp. 259-279.

39. Ruggiero, D. Community service learning, learning by design, and heritage learners: A case study. In Multiliteracies Pedagogy and Language Learning; Zapata, G.C., Manel Lacorte, M., Eds.; Palgrave Macmillan: Cham, Switzerland, 2018; pp. $129-147$.

40. Mellinger, C.D.; Jiménez, L.G. Challenges and opportunities for heritage language learners in interpreting courses in the US context. Rev. Signos Estudios Lingüística 2019, 52, 950-974.

41. Finegan, C. The interpreter as researcher: Ethical heritage interpretation in Indigenous contexts. J. Herit. Tour. 2019, 14, 282-294. [CrossRef]

42. Pichler, D.C.; Lillo-Martin, D.; Palmer, J.L. A short introduction to heritage signers. Sign Lang. Studies 2018, 18, 309-327. [CrossRef]

43. Fedotova, N.L.; Stampoulidi, Z.A. Principles of Design of a Culture-Oriented Russian Language Textbook for Greek GuidesInterpreters. филологический класс 2020, 3, 207-218.

44. Belpoliti, F.; Pérez, M.E. Service learning in Spanish for the health professions: Heritage language learners' competence in action. Foreign Lang. Ann. 2019, 52, 529-550. [CrossRef]

45. Tamura, T. Qualification and Translation Accuracy Issues of Law-Enforcement Officers Serving as Interpreters in the US: Quantitative Analysis of Court-Ruling-Derived Data. Interpret. Transl. Stud. 2019, 19, $23-44$.

46. Ji, M.; Laviosa, S. (Eds.) The Oxford Handbook of Translation and Social Practices; Oxford University Press: Oxford, UK, 2021. [CrossRef]

47. Edensor, T. National Identity, Popular Culture and Everyday Life; Routledge: London, UK, 2020.

48. Cronin, M. Translation and Identity; Routledge: London UK, 2006.

49. Neves, J. Cultures of Accessibility: Translation making cultural heritage in museums accessible to people of all abilities. In The Routledge Handbook of Translation and Culture; Routledge/Taylor \& Francis: London, UK, 2018; pp. 415-430.

50. Zhiguo, L. Translations of Introductive Texts of Intangible Cultural Heritage. Foreign Lang. Lit. 2017, 33, 117-121.

51. Kreps, C. Indigenous curation, museums, and intangible cultural heritage. In Intangible Heritage; Smith, L., Akagawa, N., Eds.; Routledge: London, UK, 2008; pp. 193-208.

52. Saipradist, A.; Staiff, R. Crossing the cultural divide: Western visitors and interpretation at Ayutthaya World Heritage Site, Thailand. J. Herit. Tour. 2008, 2, 211-224. [CrossRef]

53. Rubenson, S. Translating the Tradition: Some remarks on the Arabization of the Patristic Heritage in Egypt. Mediev. Encount. 1996, 2, 4-14. [CrossRef]

54. Selamet, J. Indonesian Batik Translation: A Case Study. Int. J. Vis. Des. 2018, 12, 11-17. [CrossRef]

55. Garzaniti, M. Il termine russo frjag e le sue radici nelle relazioni culturali e artistiche fra la Russia e l'Italia. In The Language of Art and Cultural Heritage: A Plurilingual and Digital Perspective; Pano Alamán, A., Zotti, V., Eds.; Cambridge Scholar Publishing: Newcastle upon Tyne, UK, 2020; pp. 104-120.

56. Henkel, D. Lexical Association as an Indicator of Conceptual Convergence and Divergence in English, French and Italian. In The Language of Art and Cultural Heritage: A Plurilingual and Digital Perspective, Pano Alamán, A., Zotti, V., Eds.; Cambridge Scholar Publishing: Newcastle upon Tyne, UK, 2020; pp. 120-139.

57. Oegema, G.S. The Heritage of Jewish Apocalypticism in Late Antique and Early Medieval Judaism, Christianity, and Islam. In Vehicles of Transmission, Translation, and Transformation in Medieval Textual Culture; Wisnovsky, R., Fraenkel, C., Wallis, F., Claire Fumo, J., Eds.; Brepols Publishers: Turnhout, Belgium, 2012; pp. 103-128. [CrossRef]

58. Mandair, A.P.S. Religion and the Specter of the West: Sikhism, India, Postcoloniality, and the Politics of Translation; Columbia University Press: New York, NY, USA, 2009.

59. Booms, H.; Joldersma, H.; Klumpenhouwer, R. Society and the formation of a documentary heritage: Issues in the appraisal of archival sources. Archivaria 1987, 24, 69-107. 
60. Nakhodkina, A.A. Cultural heritage in a current context: Case of Olonkho translation. Арктика Ххі Век. Гуманитарные Науки 2015, 2, 86-92.

61. EvePocock, C.; Lilley, I. Who benefits? World heritage and Indigenous people. Herit. Soc. 2017, 10, 171-190. [CrossRef]

62. Trivedi, H. Translating culture vs. cultural translation. In Translation-Reflections, Refractions, Transformations, Benjamins Translation Library 71; St-Pierre, P., Kar, P.C., Eds.; John Benjamins Publishing Company: Amsterdam, The Netherlands, 2007 ; pp. $277-287$. [CrossRef]

63. Buden, B.; Nowotny, S.; Simon, S.; Bery, A.; Cronin, M. Cultural translation: An introduction to the problem, and responses. Transl. Stud. 2009, 2, 196-219. [CrossRef]

64. Falser, M. Cultural heritage and architectural history between appropriation, substitution and translation: Plaster casts of Angkor Wat in a transcultural perspective. In Engaging Transculturality; Routledge: London, UK, 2019; pp. $247-263$.

65. Baynham, M.; Lee, T.K. Translation and Translanguaging; Routledge: London, UK, 2019.

66. Chrobak, M. For a Tin Ingot: The Archeology of Oral Interpretation. Przekładaniec. J. Lit. Transl. Spec. Issue 2013, 87-101. [CrossRef]

67. Piacentini, D. Il verbo 'tradurre' ed il termino 'tradutorre' nel Vicino Oriente. Tre esempi: Sumerico, eblaita, fenicio." Mutuare, interpretare, tradurre: Storie di culture a confronto. In Atti del $2^{\circ}$ Incontro «Orientalisti» (Roma, 11-13 dicembre 2002); Regalzi, G., Ed.; Associazione Orientalisti: Rome, Italy, 2020; pp. 13-38. Available online: www.orientalisti.net/atti2002.pdf (accessed on 1 February 2021).

68. The Earliest Depiction of an Interpreter (n/d). Available online: https://unprofessionaltranslation.blogspot.com/2010/07/ earliest-depiction-of-interpreter.html (accessed on 1 February 2021).

69. Maspero, G. Popular Stories of Ancient Egypt; ABC-CLIO: Santa Barbara, CA, USA, 2002.

70. Kurz, I. The Rock Tombs of the Princes of Elephantine. Earliest References to Interpretation in Pharaonic Egypt. Babel 1985, 31, 213-218. [CrossRef]

71. Rosetta Stone (n/d). Available online: https://blog.britishmuseum.org/everything-you-ever-wanted-to-know-about-therosetta-stone/ (accessed on 1 February 2021).

72. Ray, J. The Rosetta Stone and the Rebirth of Ancient Egypt; Harvard University Press: Cambridge, MA, USA, 2007.

73. The Code of Hammurabi (n/d). Available online: https://www.louvre.fr/en/oeuvre-notices/law-code-hammurabi-kingbabylon (accessed on 1 February 2021).

74. Hermann, A. Interpreting in Antiquity. In The Interpreting Studies Reader, Eds. Pochhacker, F., Shlesinger, M., Eds.; Routledge Language Readers: London, UK, 2002; pp. 15-22.

75. Herodotus; With an English translation by A. D. Godley; Harvard University Press: Cambridge, MA, USA; W. Heinemann: London, UK, 1920.

76. Mairs, R. Hermēneis in the Documentary Record from Hellenistic and Roman Egypt: Interpreters, translators and mediators in a bilingual society. J. Anc. Hist. 2020, 8, 50-102. [CrossRef]

77. Baines, J. Visual and Written Culture in Ancient Egypt; Oxford University Press: Oxford, UK, 2007.

78. Vischak, D. Community and Identity in Ancient Egypt: The Old Kingdom Cemetery at Qubbet el-Hawa; Cambridge University Press: Cambridge, UK, 2014.

79. Burduşel, E.N. A Cultural Approach to Legal Translation: Contemporary Perspectives and Challenges. Rev. Transilv. 2019, 11, 82-86.

80. Pozzo, B. Legal transplant and legal translation: How language impacts on the reception of foreign legal models. Legal Translation: Current Issues and Challenges in Research, Methods and Applications; Simonnæs, I., Kristiansen, M., Eds.; Frank \& Timme GmbH: Berlin, Germany, 2019; pp. 65-86.

81. Wolfsteller, R. Out of sync: The failed translation of international human rights in the creation of the UK Human Rights Act. J. Hum. Rights 2020, 19, 1-19. [CrossRef]

82. Harper, R.F. (Ed.) The Code of Hammurabi, King of Babylon, about 2250 BC: Autographed Text, Transliteration, Translation, Glossary, Index of Subjects, Lists of Proper Names, Signs, Numerals, Corrections and Erasures, with Map, Frontispiece and Photograph of Text; University of Chicago Press: Chicago, IL, USA, 1904.

83. Bustanov, A.K.; Kemper, M. (Eds.) From Mirasism to Euro-Islam: The Translation of Islamic Legal Debates into Tatar Secular Cultural Heritage. In Islamic Authority and the Russian Language: Studies on Texts from European Russia, the North Caucasus and West Siberia; Pegasus: Amsterdam, The Netherlands, 2012.

84. Kucherov, S. Indigenous and Foreign Influences on the Early Russian Legal Heritage. Slav. Rev. 1972, 31, 257-282. [CrossRef]

85. Kasirer, N. Translating Part of France's Legal Heritage: Aubry and Rau on the Patrimoine. Rev. Générale Droit 2008, 38, 453-493. [CrossRef]

86. Waelkens, L. Amne Adverso: Roman Legal Heritage in European Culture; Leuven University Press: Leuven, Belgium, 2015.

87. Lipovac, N.; Popović, G.S.; Robina, M. The Understanding of Professional and Legal Terms in Physical Planning-Better Protection of Cultural Heritage. In Cultural Heritage-Possibilities for Spatial and Economic Development; University of Zagreb: Zagreb, Croatia, 2015; pp. 18-19.

88. Boules, E.E. Ramses II in Face of Asian Deities: Some New Considerations. J. Assoc. Arab Univ. Tour. Hosp. 2020, 18, 57-75. [CrossRef]

89. Langdon, S.; Gardiner, A.H. The Treaty of Alliance between Hattušili, King of the Hittites, and the Pharaoh Ramesses II of Egypt. J. Egypt. Archaeol. 1920, 6, 179-205. [CrossRef] 
90. Beckman, G. Hittite treaties and the development of the cuneiform treaty tradition. In Die Deuteronomistischen Geschichtswerke: Redaktions Und Religionsgeschichtliche Perspektiven Zur "Deuteronomismus"; Witte, M., Ed.; Gruyter: Berlin, Germany, 2006; pp. 279-301.

91. Scala, R. Die Staatsvertrage des Altertums; CH Beck: Leipzig, Germany, 1898; pp. 6-12. [CrossRef]

92. Feldbrugge, F. The Treaties with Byzantium. The Zakon Russkii. In A History of Russian Law; Brill: Leiden, Netherlands, 2017; pp. 85-100. [CrossRef]

93. Heck, P. Übersetzungsprobleme im frühen Mittelalter; Mohr: Tübingen, Germany, 1931.

94. Hattenhauer, H. Das Europäische Rechtsgeschichte; BoD: Norderstedt, Germany, 2019.

95. Šarčević, S. New Approach to Legal Translation; Klawer Law International: Hague, The Netherlands, 1997.

96. Stolte, B.H. Thirty Years Later. Past, Present and Future of Editing the Basilica. Subseciva Groningana 2019, 10, 163-186. [CrossRef]

97. Daniel, J.; Kabatek, J. (Eds.) Lengua Medieval y Tradiciones Discursivas en la Península Ibérica: Descripción Gramatical: Pragmática Histórica: Metodología; Iberoamericana; Editorial Vervuert: Madrid, Spain, 2000.

98. Lowenthal, D. Natural and cultural heritage. Int. J. Herit. Stud. 2005, 11, 81-92. [CrossRef]

99. Sciacchitano, E. Building the Legacy of the European Year of Cultural Heritage 2018. DigitCult-Sci. J. Digit. Cult. 2018, 3, 25-30. [CrossRef]

100. Bashforth, M.; Benson, M.; Boon, T.; Brigham, L.; Brigham, R.; Brookfield, K.; Brown, P.; Callaghan, D.; Calvin, J.P.; Courtney, R.; et al. Socialising heritage/socialising legacy. In Valuing the Impact of Collaborative Research: Theory, Methods and Tools; Facer, K., Pahl, K., Eds.; Policy Press: Bristol, UK, 2017; pp. 85-106.

101. Weissbort, D.; Eysteinsson, Á. (Eds.) Translation: Theory and Practice: A Historical Reader; Oxford University Press: Oxford, UK, 2006.

102. Biguenet, J.; Schulte, R. (Eds.) Theories of Translation: An Anthology of Essays from Dryden to Derrida; University of Chicago Press: Chicago, IL, USA, 2017.

103. Snell-Hornby, M. A forgotten pioneer? The legacy of Otto Kade in Translation Studies today. In Quo Vadis Translatologie? Wotjak, G., Ed.; Frank \& Timme Gmb: Berlin, Germany, 2007; pp. 387-395.

104. Špirk, J. Czechoslovak Translation Studies: Depreciated Legacy or Inspiration for Today? In Going East: Discovering New and Alternative Traditions in Translation Studies; Schippel, L., Zwischenberger, C., Eds.; Frank \& Timme GmbH: Berlin, Germany, 2016; pp. 77-98.

105. Bernardo, A.M. Friedrich Schleiermacher's Legacy to Contemporary Translation Studies. In Rereading Schleiermacher: Translation, Cognition and Culture; Seruya José, T., Miranda Justo, M., Eds.; Springer: Berlin/Heidelberg, Germany, 2016; pp. 41-53. [CrossRef]

106. Hodges, C. Introduction: Reflection on the Art of Literary Translation and the Legacy of Langston Hughes. Langston Hughes Rev. 1985, 4, vi-ix. Available online: http:/ / www.jstor.org/stable/26432723 (accessed on 1 February 2021).

107. Kennedy, G.A. Cicero's oratorical and rhetorical legacy. In Brill's Companion to Cicero; May, J.M., Ed.; Brill: Leiden, The Netherlands, 2002; pp. 481-501. [CrossRef]

108. Tayyebi, A. (Un) Translatability of the Qur'an: A Colonial Legacy? Transl. Stud. 2013, 11, 100-116.

109. Trueman, C. Luther's Legacy. Theol. Stud. 1995, 56, 188.

110. Gémar, J.-C. La traduction juridique et son enseignement: Aspects théoriques et pratiques. Meta 1979, 24, 35-53. [CrossRef]

111. Su, X.; Li, X.; Wu, Y.; Yao, L. How is intangible cultural heritage valued in the eyes of inheritors? Scale development and validation. J. Hosp. Tour. Res. 2020, 44, 806-834. [CrossRef]

112. Roland, G. The deep historical roots of modern culture: A comparative perspective. J. Comp. Econ. 2020, 48, 483-508. [CrossRef]

113. Engberg, J. Comparative law for legal translation: Through multiple perspectives to multidimensional knowledge. Int. J. Semiot. Law-Rev. Int. Sémiotique Jurid. 2020, 33, 263-282. [CrossRef]

114. De Jonge, W. Sustainable renewal of the everyday Modern. J. Archit. Conserv. 2017, 23, 62-105. [CrossRef]

115. Buondonno, E. Climate Changings: New Paradigms of Contemporary Architecture. In New Metropolitan Perspectives NMP 2020. Smart Innovation, Systems and Technologies; Bevilacqua, C., Calabrò, F., Della Spina, L., Eds.; Springer: Cham, Switzerland, 2021; Volume 178, pp. 1962-1971. [CrossRef]

116. Arnés García, M.; Yagüe, J.L.; de Nicolás, V.L.; Díaz-Puente, J.M. Characterization of Globally Important Agricultural Heritage Systems (GIAHS) in Europe. Sustainability 2020, 12, 1611. [CrossRef]

117. Roy, V. Integrating Indigenous Systems of Medicines in the Healthcare System in India: Need and Way Forward. In Herbal Medicine in India; Sen, S., Chakraborty, R., Eds.; Springer: Singapore, 2020. [CrossRef]

118. Djabarouti, J. Stories of feelings and things: Intangible heritage from within the built heritage paradigm in the UK. Int. J. Herit. Stud. 2020, 1-16. [CrossRef]

119. Hawkins, S. Undisciplinable: The Place of Translation Studies within the History of Interdisciplinarity in the United States. Transfer 2019, 16, 182-201.

120. Rogers, M. Specialised translation today: A view from the JoSTrans bridge. JoSTrans J. Spec. Transl. 2018, 30, 3-22.

121. Mohanty, A.; Dash, D. Education for sustainable development: A conceptual model of sustainable education for India. Int. J. Dev. Sustain. 2018, 7, 2242-2255.

122. Mensah, J.; Casadevall, S.R. Sustainable development: Meaning, history, principles, pillars, and implications for human action: Literature review. Cogent Soc. Sci. 2019, 5, 1653531. [CrossRef]

123. Harrison, R. On Heritage Ontologies: Rethinking the Material Worlds of Heritage. Anthropol. Q. 2018, 91, 1365-1383. [CrossRef] 
124. Harrison, R. Heritage Futures: Comparative Approaches to Natural and Cultural Heritage Practices; UCL Press: London, UK, 2020.

125. Tvaronavičienė, M.; Tarkhanova, E.; Durglishvili, N. Sustainable economic growth and innovative development of educational systems. J. Int. Stud. 2018, 11, 248-256. [CrossRef]

126. ISO 20228:2019. Interpreting Services—Legal Interpreting-Requirements; ISO: Switzerland, Geneva, 2019; 22p.

127. ISO 20771:2020. Legal Translation—Requirements; ISO: Switzerland, Geneva, 2019; 24p.

128. Almazova, N.; Bernavskaya, M.; Barinova, D.; Odinokaya, M.; Rubtsova, A. Interactive learning technology for overcoming academic adaptation barriers. In Proceedings of the Conference "Integrating Engineering Education and Humanities for Global Intercultural Perspectives", St. Petersburg, Russia, 25-27 March 2020; Springer: Cham, Switzerland, 2020; pp. 786-794.

129. Hina, S.; Dominic, P.D.D.; Zaidi, K.S. Use of interactive tools for teaching and learning practices in higher education institutions. Int. J. Bus. Innov. Res. 2020, 22, 469-487. [CrossRef]

130. Podara, A.; Giomelakis, D.; Nicolaou, C.; Matsiola, M.; Kotsakis, R. Digital Storytelling in Cultural Heritage: Audience Engagement in the Interactive Documentary New Life. Sustainability 2021, 13, 1193. [CrossRef]

131. Orlando, M. Training and educating interpreter and translator trainers as practitioners-researchers-teachers. Interpret. Transl. Trainer 2019, 13, 216-232. [CrossRef]

132. Prieto Ramos, F. Legal translation studies as interdiscipline: Scope and evolution. Meta J. Trad./Meta Transl. J. 2014, 59, $260-277$. [CrossRef] 